\title{
RECENT CRITICISM AND REFERENCE
}

\section{THE JOYCE PARADOX}

by ARNOLD M. GOLDMAN

This book attempts to clarify current Joyce criticism by polarizing attitudes which have been taken toward his work. This polarization forms the basis for a new view which takes account of divergent tendencies within Joyce's fiction itself. The Joyce Paradox especially concentrates on a new interpretation of the structure of Ulysses.

$180 \mathrm{pp} . \quad \$ 4.95$

\section{INTERNAL EVIDENCE}

\section{AND ELIZABETHAN DRAMATIC AUTHORSHIP}

\section{An Essay in Literary History and Method}

\section{by S. SCHOENBAUM}

Even though the Elizabethan period was the greatest in English stage history, its documentary records of authorship are often fragmentary, contradictory, or erroneous. Professor Schoenbaum deals with the literature, origins, and history of inquiries into Elizabethan dramatic authorship; he also provides a methodology for students venturing into this difficult field of literary investigation. 281 pp. $\quad \$ 7.50$

\section{AN OLD ENGLISH ANTHOLOGY}

\section{edited by W. F. BOLTON}

W. F. Bolton has conceived a book that illustrates the progress of Old English prose and poetry during the classical period. His selections are for the most part complete; they have been carefully edited and are introduced by brief but substantial comments.

\section{PATTERNS OF LOVE AND COURTESY}

\section{Essays in Memory of C. S. Lewis}

edited by JOHN LAWLOR

Scholars who enjoyed the friendship of the late C. S. Lewis have composed these essays, which are expositions on and variations of some of Lewis' own themes. The contributors include John Stevens, Colin Hardie, Gervase Mathew, D. S. Brewer, Elizabeth Salter, J. A. W. Bennett, John Lawlor, N. K. Coghill, R. T. Davies, and P. C. Bayley.

200 pp. $\quad \$ 4.95$

\section{MIDDLE ENGLISH ROMANCES edited by A. C. GIBBS}

\section{TEN MIRACLE PLAYS} edited by R. GEORGE THOMAS

These are the first two volumes in the York Medieval Texts series, which is intended to make available not only standard works of the period, but also materials that were formerly accessible only to specialists. The General Editors of the series are Elizabeth Salter and Derek Pearsall, who teach at the University of York. each about $185 \mathrm{pp}$.

\section{NORTHWESTERN UNIVERSITY PRESS}




\section{For Members Only}

\section{FORTHCOMING MEETINGS AND CONFERENCES OF GENERAL INTEREST}

CONFERENCE IN OBSERVANCE OF THE FOURTH CEN TENNIAL OF THE DEATH OF FRAY BARTOLOME DE LAS CASAS, 29-30 September and 1 October 1966, Dubuque, Iowa. Address Edward J. Schuster, Dept. of Modern Foreign Languages, Loras College, Dubuque, lowa.

BIBLIOGRAPHICAL SOCIETY OF AMERICA, 7.8 October 1966, Hartford and Middletown, Connecticut. Address Edward Naumberg, Jr., P.O. Box 397, Grand Central Station New York, N.Y. 10017.

AMERICAN COUNCIL ON EDUCATION, 12-14 October 1966, New Orleans, La. Address ACE, 1785 Massachusetts Ave., N.W., Washington, D.C. 20036.

ROCKY MOUNTAIN MODERN LANGUAGE ASSOCIA TION, 14-15 October 1966, Univ. of Utah. Address Clarice Short, Dept. of English, University of Utah, Salt Lake City 84102 .

SOUTH ATLANTIC MODERN LANGUAGE ASSOCIATION, 10-12 November 1966, Charlotte, N.C. Address Richard Sey10-12 November 1966, Charlotte, N.C. Address Rich
mour, Box 4701 Duke Station, Durham, N.C. 27706.

SOUTH CENTRAL MODERN LANGUAGE ASSOCIATION, 10-11 November 1966, Austin, Texas. Address Andrew Louis, Dept. of Germanics, Rice University, Houston, Texas 77001.

NATIONAX COUNCIL OF TEACHERS OF ENGLISH, 24. 26 Novembet 1966, Houston, Texas. Address James R. Squire, 508 South 6th St., Champaign, IIl. 61822.

PHILOLOGICAL ASSOCIATION OF THE PACIFIC COAST 26-27 November 1966, Berkeley, Calif. Address R. S. Meyerstein, Dept. of Foreign Languages, San Fernando Valley State College, Northridge, Calif. 91326 .

SYMPOSIUM OF THE DEPT. OF GERMANIC LAN GUAGES AT THE UNIV. OF TEXAS, 28-30 Novembar 1966. Address Stanley N. Werbow, Dept. of Germanic Langs., Univ. of Texas, Austin 78712.

COLLEGE ENGLISH ASSOCIATION, 27 December 1966 New York City. Address Donald Sears, Howard University, Washington, D.C. 20001 .

MODERN LANGUAGE ASSOCIATION, 27-29 December 1966, Statler Hilton and Sheraton Atlantic Hotels, New York City, Address John H. Fisher, MLA, 4 Washington Place, New York, N.Y. 10003.

AMERICAN HISTORICAL ASSOCIATION, 28-30 Decem. ber 1966, New York Hilton, New York City. Address Paul L. Ward, 400 A Street, S.E., W ashington, D.C. 20003.

AMERICAN NAME SOCIETY, 29-30 December 1966, Statler Hilton, New York City. Address Louiso M. Harder, c\% State Univ. Coll., Potsdam, N.Y. 13676.

AMERICAN STUDIES ASSOCIATION, 27-29 December 1966 Statler Hilton, New York City. Address Robert F. Lucid, Box 46, College Hall, Univ, of Penrsylvania, Philadelphia Box 46 ,

THE HUMANITIES AND THE NATION. Hubert $H$. Humphrey, Vice President of the United States, addressed the annual meeting of the ACLS in Washington, D.C., on 20 January 1966. We are grateful to him and to the ACLS for permission to reprint the following excerpts from his moving statement: "It is a special privilege and a joy to be with you tonight and to join with you in celebrating the establishment of the $\mathrm{Na}$ tional Foundation for the Arts and the Humanities. I have long valued and admired the work of your Council and of its constituent organizations. . . For many years, men in public life have professed their love of the arts and the humanities. They have also professed their profound regret that they could do nothing tangible to help them. Now, that day is over, thank goodness. And it's over thanks in large part to your staunch friends in the Congress, friends that you have noted here tonight. Because of them, things have changed. I know that Senator Pell and Senator Javits, Senator Clark and Senator Gruening and Senator Yarborough, just to mention a few in the Senate, and Congressman Moorhead and Congressman Thompson and Congressman Fogarty and Congressman Widnall and many
SPEECH ASSOCIATION OF AMERICA, 27-30 December 1966, Conrad Hilton Hotel, Chicago. Address William Work, Statler Hilton Hotel, New York, IN.Y. $1000 \mathrm{I}$.

AMERICAN PHILOLOGICAL ASSOCIATION, 28-30 De. cember 1966, Commodore Perry Hotel, Toledo, Ohio. Adlege in the Bronx, Bronx, N.Y. 10468.

LINGUISTIC SOCIETY OF AMERICA, 28.30 December 1966, Hotel Roosevelt, New York City. Address A. A. Hill, Box 8120 University Station, Austin, Texas 78712.

NATIONAL ENGLISH TEACHER PREPARATION STUDY, 26.28 January 1967, Palmer House, Chicaso, Illinois. Ad. dress William P. Viall, Western Michigan Univ., Kalamazoo 49001 .

CONFERENCE ON TEACHING ENGLISH TO SPEAKERS OF OTHER LANGUAGES (TESOL), 13.15 March 1967, Miami Beach, Florida. Address David P. Harris, Americat Language Institute, Geotgetown Univ., 3605 o Street, N.W., W ashington, D.C. 20007.

NORTHEAST CONFERENCE ON THE TEACHING OF FOREIGN LANGUAGES, 13.15 April 1967, Sheraton-Park son, Contecticut 06443 .

SECOND INTERNATIONAL CONGRESS ON THE EN. LIGHTENMENT, 22-31 August 1967, Univ. of St. Andrews,
Address S. S. B. Taylor, St. Salvator's College, The UniAddress S. S. B. Taylor, St.
versity, St. Andrews, Scotland.

TENTH INTERNATIONAL CONGRESS OF LINGUISTS, 22 August-2 September 1967, Bucharest, Rumania. Address $X$-ème Congrès International des Linguistes, Comité d'Organisation, 20 I.C. Frimu, Bucarest, 22, Rumania.

FOURTH INTERNATIONAL CONGRESS ON MEDIAEVAL PHILOSOPHY, 27 August-2 September 1967, Univ, of Montréal. Address Executive Committee, Apartment 23, 2910 Maplewood Ave., Montréal 26, Canada.

FIFTH CONGRESS OF THE INTERNATIONAL COMPARATIVE LITERATURE ASSOCIATION, 30 August-5, Septem5th ICLA Congress, Faculty of Philology, post fah 556, Bth ICLA Congress,

INTERNATIONAL ASSOCIATION OF UNIVERSITY PRO FESSORS OF ENGLISH, 20.25 August 1968 , Dublin. $A d$ dress Professot P. H. Butter, Dept. of English, The University, Glasgow, W.2.

MHRA JUBILEE (Modern Humanities Research Association Invitational Conference), Cambridge, England, 25-31 Augus 1968 (see PMLA, March 1966, p. A-10)

others share with me tonight my pride that Congress has provided at long last financial support and legislative support-in fact, a commitment of the American people-for the arts and the humanities.

"In 1964 we achieved a significant first step, the creation of the National Council on the Arts. But the establishment of a Foundation, endowed with real money, still seemed remote. Then came the First Session of this 89th Congress. Thanks to the determined leadership by President Johnson-and he stood with us all the way-and to the skilled floor work of your friends in the Congress-and it took a good deal of open field running-we did break through. We scored a touchdown.

"As you undoubtedly recall, the debates in Congress focused largely on the arts rather than on the humanities. . . . Moreover, by their very nature, the performing arts are public in character, and they presuppose the existence of an audience. Their practitioners are public figures and possess the quality that we call glamour. But the practitioners of the humanities are, for the most part, free of the more dubious blessings of public attention. Very few laymen profess with conf- 


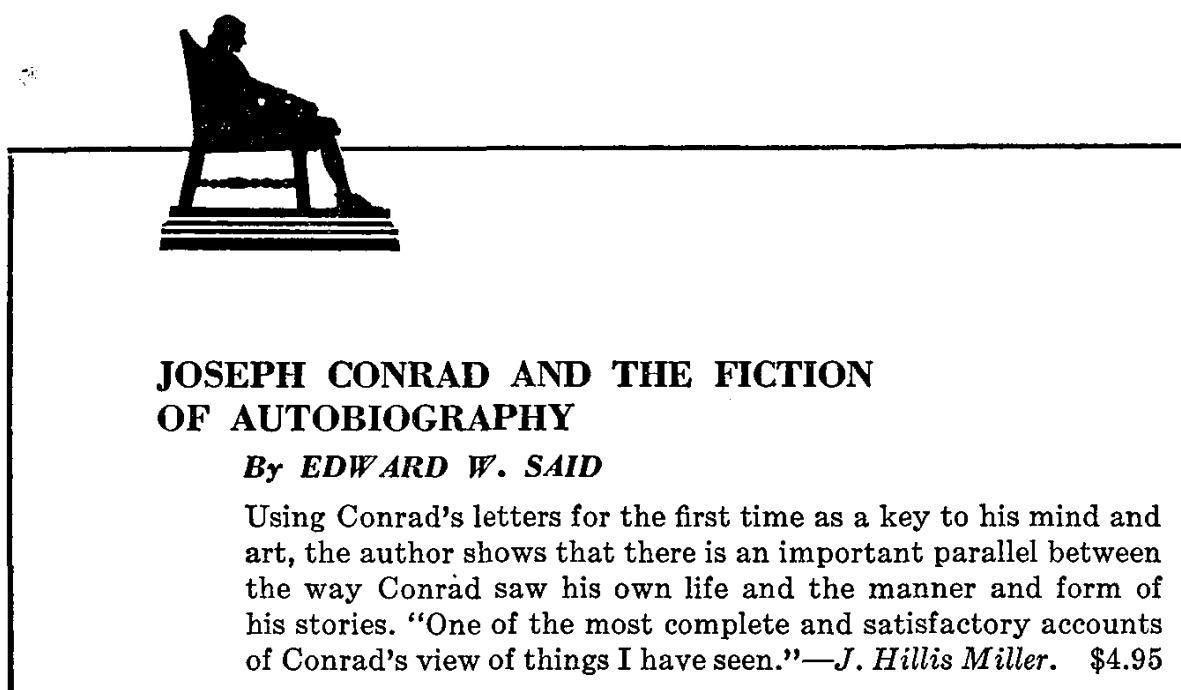

\section{MIGUEL DE UNAMUNO}

By JULIAN MARIAS

Translated by Frances M. López-Morillas

In literary technique, the Spanish philosopher-novelist Unamuno was an innovator. Discussing various metaphysical terms as they appear in Unamuno's works, the author demonstrates that this major intellectual was a forerunner of existentialism whose concepts were an original force in the development of modern philosophy. $\$ 4.75$

\section{THE DRAMATIC CRAFTSMANSHIP OF MORETO BY FRANK P. CASA}

Based on a careful examination of five plays, this first thorough investigation of the relation of Moreto's works to their sources shows Moreto to have been not merely a clever manipulator of other people's materials, but a dramatist with a high degree of artistic integrity. Harvard Studies in Romance Languages, 29. $\$ 5.00$

\section{THE JOURNALS AND MISCELLANEOUS NOTEBOOKS OF RALPH WALDO EMERSON \\ Volume VI, 1824-1838 \\ Edited by RALPH H. ORTH}

The quotation books and miscellaneous notebooks contained in this volume include entries from a great variety of writers, Emerson's own translations of Goethe, and excerpts from his brother Charles's letters. Annotations indicate how he referred to these books in composing sermons. Belknap. Illustrated. $\$ 12.00$

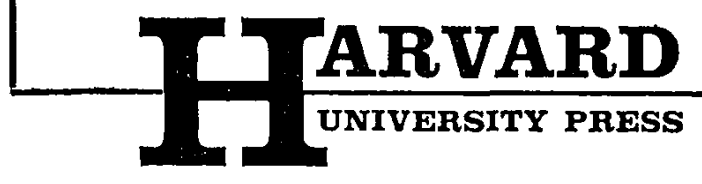




\section{For Members $O_{n} l_{y}-C_{o n t i n u e d}$}

dence to know what they like in philosophy or linguistics, and fewer still say so. Editorial writers, columnists and commentators of all sorts are not constantly looking over your shoulder and advising you what to do and what not to do, what to say and what to leave unsaid-unless, of course, you write history about the living as well as the dead.

"But even privacy can be pushed too far. As men and women who have dedicated your lives to the service and the honor of knowledge, you have every right to expect a reasonable degree of public understanding and recognition. To look for a moment at the other side of the coin, the humanities have now formally entered the competition for public funds-and the arena is crowded, I want you to know. You therefore have a certain responsibility for helping the public and your elected representatives here in Washington to gain some appreciation of what you do and why it is important. As one who has been around Washington now for seventeen years, I suggest that you ought not to assume that people really know how important your work is. The eloquent report of your Commission on the Humanities was a welcome step in this direction, and it is no exaggeration to say that this report won for the Humanities an equal place in the new National Foundation. But the process of communication with the public and the Congress must be a continuing one. You can never assume that the case has been made once and for all.

"Perhaps I, as an amateur humanist and a professional public servant, can be of some help by telling you what I consider is the vital contribution of the humanities to our national life. First of all, a thorough grounding in the humanities sharpens in the individual the quality of choice. Choice is a vital part of life, and nowhere is it more important than in government. Indeed, a wise Frenchman once observed that to gov. ern is to choose. Each choice taken-indeed, each choice deferred or avoided-has consequences reaching far into the future. There are many specialists who can provide us with the facts relevant to decisions: the 'what' and the 'where' and the 'when' and the 'how.' But when they have laid all their facts upon the table, an essential element is still missing: the 'why.' That's where we come to the humanities. No narrow speciality or expertise can provide the full and essential grasp of the continuity of past, present and future that the humanities do.

"Let me make it clear that I do not believe the humanities must be justified on the grounds of any immediate and practical results. In the most fundamental sense, they are good in themselves simply because they are the bearers and preservers of what we call civilization. The historian who brings order out of the tangled record of the past; the critic who casts new light on works of literature, painting or music; the philosopher who questions and clarifies our most basic assumptions-all of these serve to enrich our lives and to expand our vision. Together they constitute one of our most precious national resources.

"One of the most important facts about the establishment of the National Endowment for the Humanities is that it does constitute a recognition of the humanities for their own sake. Humanist scholars, as you are all well aware, have long received support from the federal government. But in the past this support has always been justified in terms of something else: international cooperation, the improvement of the school curriculum, national defense, and so forth.

"Now, however, the President and the Congress have gone officially on record as holding that the strengthening of the humanities as such is in the public interest. The government has, in effect, endorsed the words of your own Commission on the Humanities: 'Through the humanities we may seek intellectual humility, sensitivity to beauty, and emotional discipline. By them we may come to know the excitement of ideas, the power of imagination, and the unsuspected energies of the creative spirit.'

"Ultimately, the fate of the humanities must rest in the hands of devoted individuals-scholars who pursue their researches wherever they may lead, guided by their own intelligence and by the canons of scholarship itself. These scholars, in their single-minded dedication to their calling, may often be deaf to the cries of the market place and the forum, and to the seductive voices of fashion and expediency.

"Certainly, the American Council of Learned Societies can be proud of its own long record of supporting worthy scholars despite the apparent lack of popular interest in what these scholars proposed to do. By maintaining and applying the most rigorous standards, often in defiance of the fashions of the day, the American Council of Learned Societies has served the humanities and the nation well.

"But the history of the Council illustrates another factor which I think is well worth mentioning on this important occasion. In every field of intellectual endeavor, in the sciences as well as in the humanities, what today appears to be the most esoteric and impractical kind of research may tomorrow prove to be of the utmost practical usefulness and importance. I stress the word "may," because I do not think the case for basic research in scholarship and the humanities should be made to rest on claims of practical utility. To be sure, you can fortify your case with examples of practical utility. But to rest your case on that premise alone, I think, is to pervert the very meaning of dedication to the humanities.

"In this connection, I can give an example or two. Your Council has taken a continuing interest in the study and analysis of languages. For many years, yours was the only organization in this country to offer encouragement and support for scholarly work in what were then termed 'exotic' languages. Suddenly, with our involvement in World War II, and with our armed forces spread over the entire globe, we found ourselves in urgent need of communication with peoples who spoke some of these same exotic languages. Besides other scholars, we also needed linguists whose knowledge of the basic structure of language enabled them to develop new and more effective techniques of language instruction for the armed forces.

"The same story can be told of the development in this country of area studies, in which your Council has also played a leading role. Our possession of substantial numbers of highly trained and skilled experts on the peoples and cultures of Eastern Europe, the Middle 


\title{
THE WESLEYAN EDITION \\ OF THE WORKS OF \\ HENRY FIELDING
}

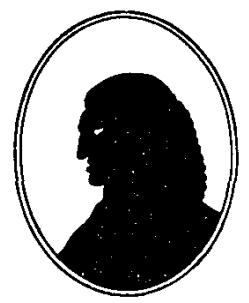

prepared under the supervision of an Advisory Board of distinguished British and American scholars, is published jointly by Clarendon Press and Wesleyan University Press. Instituted to establish and make available an authoritative text of all of Fielding's writings, it will run to some sixteen volumes, of which this is the first.

\section{Joseph Andrews}

\author{
Edited by MARTIN C. BATTESTIN \\ Associate Professor of English Literature \\ in the University of Virginia
}

\section{TEXTUAL INTRODUCTION BY FREDSON BOWERS}

$T$

HIS EDITION of Joseph Andrews inaugurates the definitive Wesleyan edition of the complete works of Henry Fielding. Primarily it is a textual edition, designed to furnish readers with both a reliable text and all other materials relevant to the history and essential meaning of the text. To this end the Introduction treats the circumstances of the novel's genesis and composition, and the facts of its printing and publication; the annotations identify and explain topical references and literary allusions. The text itself was prepared according to principles set forth in the Introduction. Appendices include the bibliographical description of the first five editions of Joseph Andrews; lists of emendations and variant readings; and an analysis of the so-called 'Murphy' editions of the novel.

500 pages $\quad 3$ plates $\quad$ Publication October 20 $\$ 10.00$

Subscribers to the entire Wesleyan Edition of the Works of Henry Fielding will receive a special discount. Please write for details.

WESLEYAN UNIVERSITY PRESS

Middletown, Connecticut 06457 


\section{For Members $O_{n} l_{y}-C_{o n t i n u e d}$}

East, Asia, Latin America, and Africa has turned out to be an invaluable national asset. The United States would simply not be able to discharge its worldwide responsibilities adequately without them. I am pleased to note that the Library of Congress, so ably represented here by its own Librarian, has made an invaluable contribution to our national security because of the competence of many of its people in these area studies. Indeed, in these cases, and others I could cite, so-called impractical scholars turned out to be more far-sighted than many of our public officials. The scholar-by his disposition, by his training, and by his environment-is peculiarly fitted to take the long and detached view of men and of societies. To do so is both his privilege and his responsibility.

"Whatever the pleasures of public life may be-and I can assure you that there are many-the opportunity for quiet contemplation is seldom among them. When I visited the home of Thomas Jefferson, and learned how much time he gave to reading and contemplation, I wondered how we do as well these days as we seem to do. I frankly envy your opportunity to ponder in depth and at length all of the ramifications of human knowledge and experience.

"I do hope that the program of the National Endowment for the Humanities will include some opportunity for scholars to impart more directly and regularly their unique perspectives and insights to those of us engaged in the business of governing and decision-making. . . .

"The establishment of the National Foundation for the Arts and the Humanities marks the beginning of a new era for the humanities in America. If $I$ might presume to give you a word of advice as you enter that era, I would simply say this: "Be true to yourselves." I hope you will continue to do what seems important to you. That's why this Foundation was established-not to do what I say you should do, or even the President or anyone else. Be true to yourselves and to the high standards of your own disciplines, guided by the internal logic of your work and of your scholarship. This is what we expect of you in a free society. I hope that you will never succumb to the temptation to sacrifice your work and its standards to any transitory notion of expediency or popularity. You are supposed to be the rudder that holds us on at least some semblance of a straight course. Don't try to run with every shifting wind. You'll never get your sails up fast enough to avoid disaster. In your corporate capacity as the representatives and the servants of our nation's tens of thousands of humanist scholars, I hope that you will always remember your responsibility as leaders to speak and to act for your unique constituency. If your voice has been heard in the councils of government-and it has-it is not because you're adept at politics, or have any great political influence. It is because yours has been the authentic voice of dedicated scholars, exponents of intellectual excellence.

"By being true to themselves, scholars best serve not only their nation and their time, but all mankind as well." (The full text of the address was printed in the ACLS Newsletter, January and February 1966.)
B. Q. MORGAN AND THE INDEX TO PMLA. The MLA has much to be thankful to B. Q. Morgan for: sound advice and staunch support of the FL Program since its inception; many periods of arduous work in the MLA office collecting and organizing material on various programs; and reading all $P M L A$ proof and proof of most other MLA publications for the last fifteen years. We now thank him for an author-title index to PMLA, 1936-64 (\$3). This complements the index for 1884-1935 edited by Percy W. Long, and it supersedes the slender and almost unknown index for 1936-45 (PMLA, 1945, Supplement, pp. 1507-29). B. Q. Morgan deserves our heartfelt gratitude for this useful work. Now he has in hand brief biographies outlining the accomplishments of all the MLA presidents, to accompany the photographs that have been collected over the years. The humanities are, finally, about human beings and what they accomplish. The collective remembrance of our part of the humanities is to a large extent MLA and PMLA. We are grateful to B. Q. for helping us to recall both.

VARIORUM REPORT. T. W. Baldwin (Illinois) is working ahead on The Comedy of Errors and M. W. Black (Pennsylvania) on Titus Andronicus. Mark Eccles and Richard Knowles (both of Wisconsin) are editing Measure for Measure. Cyrus Hoy (Rochester) and Robert Turner (Pennsylvania) have been approved as editors of The Winter's Tale. Christopher Spencer (Illinois SU) has been approved to re-edit The Merchant of Venice (the first assignment for re-editing a Furness volume). M. A. Shaaber (Pennsylvania), Sister Evelyn Joseph, and Richard Knowles will re-edit As You Like It. We hope that these editorial plans can be formulated clearly enough and the National Endowment on the Humanities receive sufficient appropriation for the Variorum to go into high gear. The editions have long been in demand by libraries and have brought high prices on the second-hand market, and the MLA has entered into a contract with the American Scholar Publications to bring out reprints of all out-of-print Variorum editions with supplementary bibliographies. American Scholar had already reprinted Macbeth, Romeo and Juliet, Hamlet, As You Like It, and The Merchant of Venice before it received the MLA contract. The original editions of Richard the Second and Troilus and Cressida are still in print and may be ordered from J. B. Lippincott Company.

PROPOSED HENRY JAMES JOURNAL. Robert $L$. Gale and the University of Pittsburgh English Department propose to found a James journal or newsletter. A conference to discuss this prospect will be held at the MLA meeting in December. Those wishing to participate should write directly to Professor Gale, Dept. of English, Univ. of Pittsburgh. 


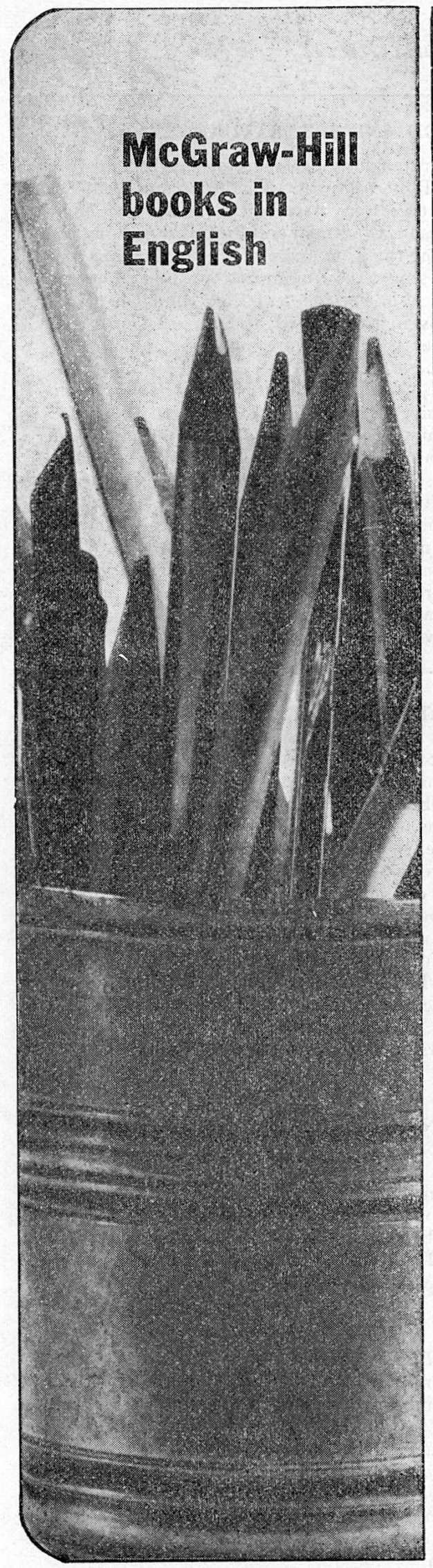

\section{VOCABULARY IMPROVEMENT: A Program for Self-Instruction}

By Nancy Davis, Indiana University. Available in December.

Designed to help the student build a practical technique for acquiring reading vocabulary skills. The first three units expand vocabulary recognition by the study of common prefixes, suffixes, and roots from Latin and Greek and their relationship to present-day meanings. The last unit develops a sense of how context clues lead to word recognition, utilizing examples from contemporary texts. An Instructor's Manual will be available.

\section{TRENDS IN LANGUAGE TEACHING}

Edited by Albert Valdman, Indiana University. 320 pages, $\$ 6.95$ clothbound. Soft-cover Text Edition also available for classroom adoption: $\$ 4.50$.

This is the first text designed to acquaint language teachers with the latest developments pertinent to their field. Major advances in a variety of disciplines relative to language learning (linguistics, psychology, audiovisual instruction, etc.) are reviewed by specialists. Techniques are described which are immediately applicable in the language classroom as well as insights and principles underlying new developments which will take place in the next decade.

\section{LANGUAGE, RHETORIC, AND STYLE}

Edited by Philip Damon, University of California at Santa Barbara; John Espey, University of California at Los Angeles; and Frederick Mulhauser, Pomona College. 480 pages, $\$ 5.95$.

A three-part essay anthology providing separate sections on the nature and use of language, the rhetoric of exposition, and the development of various prose styles. In addition, the editors provide a dozen com mentaries on individual selections and groups of selec. tions. A rigorous Teacher's Manual is available.

\section{MeGraw-Hill Book Company}

330 West 42 nd Street, New York, N. Y. 10036 


\section{For Members $O_{n} l_{y}-C_{\text {ontinued }}$}

\section{STUDY OF THE PH.D. IN ENGLISH LANGUAGE AND LITERATURE}

A study will be undertaken during 1966.67 of the Ph.D. in English in order to ascertain: 1) how the average time it takes for the candidate to proceed from B.A. to Ph.D. may be shortened without loss in quality; 2) what changes in curriculum might serve to focus the program more directly on the training of college teachers; 3 ) whether an intermediate degree for some college and junior college teachers is necessary and feasible; and 4) whether postdoctoral programs of study should be instituted for those who are particularly interested in research and writing. The study will be made under the auspices of the Modern Language Association with support from the Danforth Foundation. The Director is Don Cam. eron Allen, Sir William Osler Professor of English at Johns Hopkins University. He will work with the advice of the English Program Advisory Committee of the MLA; Fredson Bowers, Chairman and Professor of English at the University of Virginia; John C. Gerber, Chairman and Professor of English at the University of Iowa; Albert R. Kitzhaber, Professor of English at the University of Oregon; Maynard
Mack, Chairman and Professor of English at Yale University; Robert Ornstein, Chairman and Professor of English at Western Reserve University; and Theodore Andersson, Chairman and Professor of Romance Languages at the University of Texas. For the purpose of this study, the Committee will be augmented by Gustave Arlt, President of the Council of Graduate Schools in the United States, and Gordon N. Ray, President of the John Simon Guggenheim Memorial Foundation.

An initial meeting on the study was held at Johns Hopkins University on 6-7 May at which the Director and Committee consulted with representatives of twenty departments which award the Ph.D. in English. In subsequent meetings, they will consult with representatives of all departments which now award or are planning to award an English doctorate. Based upon these meetings, the collection of statistical and other information, and travel and interviews by the Director, a report will be written which will include recommendations to the profession. It is hoped that the report will be ready by September 1967 .
MLA STUDY COMMISSION INTERIM REPORT. The Commission will make an interim report to the Executive Council at its October meeting in Salt Lake City. Among its recommendations: A substantial prize for a distinguished first book by an MLA member. Improvements in faculty exchange and in vacancy lists. Term appointments for Trustees of invested funds. An annual lecture, to be given at one MLA evening ses. sion by a distinguished non-member. Inclusion of biographical information in mail ballot for election to the Executive Council, plus greater emphasis on younger nominees. The Commission earlier recommended and the Council approved a Spring 1967 meeting of officers and standing committees, along with presidents and secretaries of the five regional associations, to discuss problems affecting the Association and the profession. A subcommittee led by David Bevington (Virginia) is studying many aspects of the annual meeting, including dates apart from the Christmas holidays. Also being considered is a second meeting each year, at the end of the summer, limited in scope and designed to recapture the intimacy of the Wisconsin and Stanford campus gatherings. If either scheme should appear practicable, a generous sampling of the membership can expect to be queried via an opinion poll. Further innovations in programming are now in the discussion stage. Another subcommittee, led by Carl Woodring (Columbia), is studying the Association's involvement with FL and English Programs, and contract work for foundations and government agencies, and its expanded role as a public spokesman for the Humanities. The difficult mission of Woodring's group is to draw up guidelines for future commitments. They find themselves wrestling also with such problems as group research, information retrieval, international affliations, and automation. What are the responsibilities and opportunities of humanists, and what specifically should the MLA do or not do? The Commission welcomes advice and suggestions.
DICTIONARY OF AMERICAN REGIONAL ENGLISH. It is preparing to use, as one of its important sources, the regional literature of the United States, both past and present. To do this effectively it must first make bibliographical lists of the novels, stories, plays, poems, diaries, travel accounts, autobiographies, and the like, which relate to each of the fifty states or to specific regions of the country. So far as it can find, no total list of this sort now exists. The members of the staff have begun a compilation state by state, but they appeal to Americanists and specialists in regional literature to inform them of any existing bibliographies of this kind, whether printed or not. All aid received will be acknorledged in the eventual Dictionary. Write to Frederic G. Cassidy, Director, Univ. of Wisconsin, 2218 University Avenue, Madison 53706.

ODÖN VON HORVATTH. The Memorial Library of the University of Wisconsin now has a virtually complete Xerox copy of the Ödön von Horváth archive at the West Berlin Akademie der Künste. This material is available to all interested persons. Further information may be obtained from Professor Ian Loram, Chairman, Dept. of German, Bascom Hall, Univ. of Wisconsin, Madison 53706.

MONATSHEFTE. The October 1966 issue of Monatshefte carries a list of $\mathbf{3 5 0}$ dissertations in Germanic languages and literatures in progress at 61 universities in the U.S., Canada, Australia, New Zealand, and South Africa. The list, compiled by Peter Mollenhauer (Wisconsin), is intended to be annual. Monatshefte has also agreed to publish the entire symposium on German Realism which constituted the program of the Cerman 4 group of the MLA meeting in Chicago, December 1965 . 


\section{Do They Know Something You Don't Know? . . .}

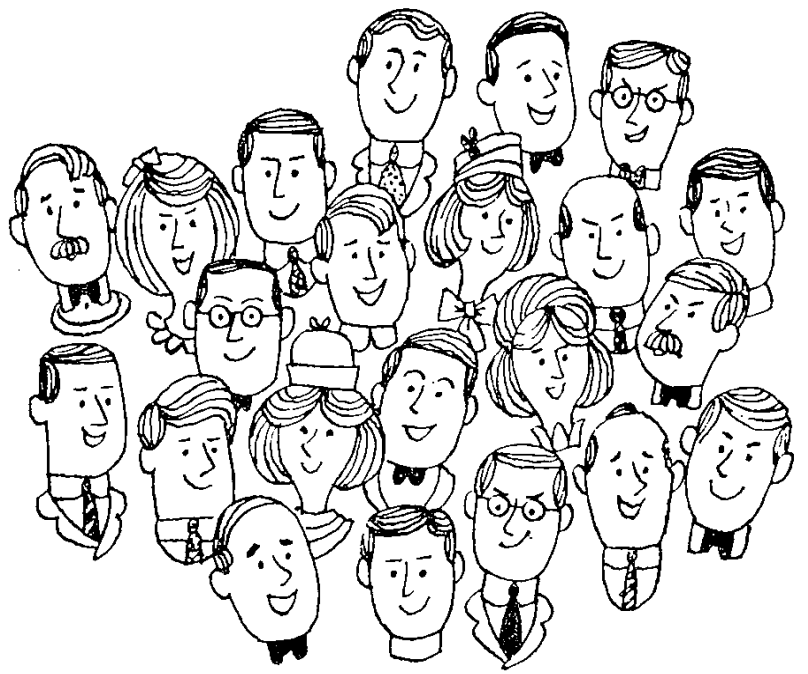

Educators bought 50\% more TIAA life insurance in 1965 than in 1964, the previous all-time high. And the average policy $(\$ 30,000)$ continues to be much higher than the average for companies insuring the general public.

It must be TIAA's new lower premium rates.

For example,

A $\$ 0,000$ policy costs ONLY $\$ 98$ at age 30. Here's how:

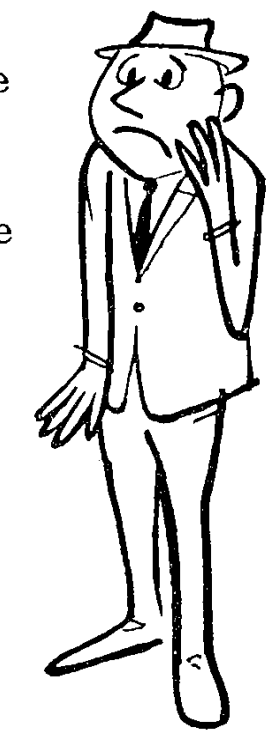

$\$ 50,000$ 20-Year Home Protection Policy

Age at Issue

Annual Premium (Payable only 16 years)

Cash Dividend End of First Year (based on 1966 dividend scale; not guaranteed for the future)

First Year Net Premium

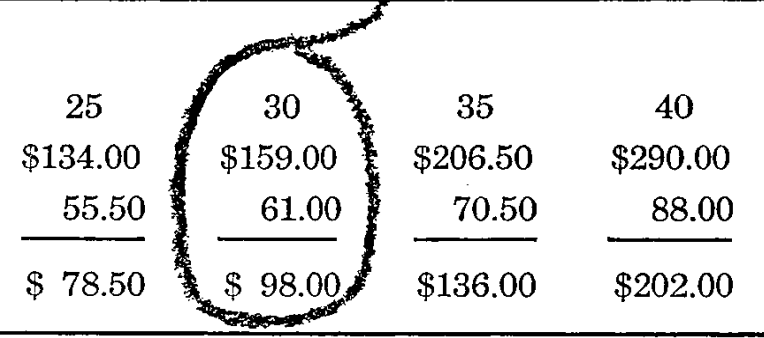

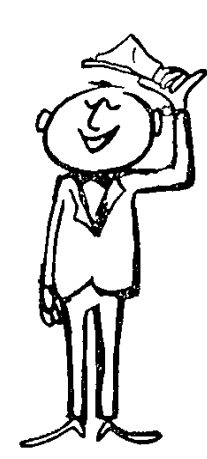

Mail the coupon for the new Life Insurance Guide and a personal illustration of TIAA policies for your age.

This is a plan of level premium Term insurance which provides its largest amount of protection initially, reducing by schedule each year over a 20year period to recognize decreasing insurance needs. There are several other insurance periods, and Home Protection policies are available at all ages under 56.

ARE YOU ELIGIBLE FOR TIAA? Yes, if you are employed by a college, university, private school, or other nonprofit educational or scientific institution that qualifies for TIAA eligibility.

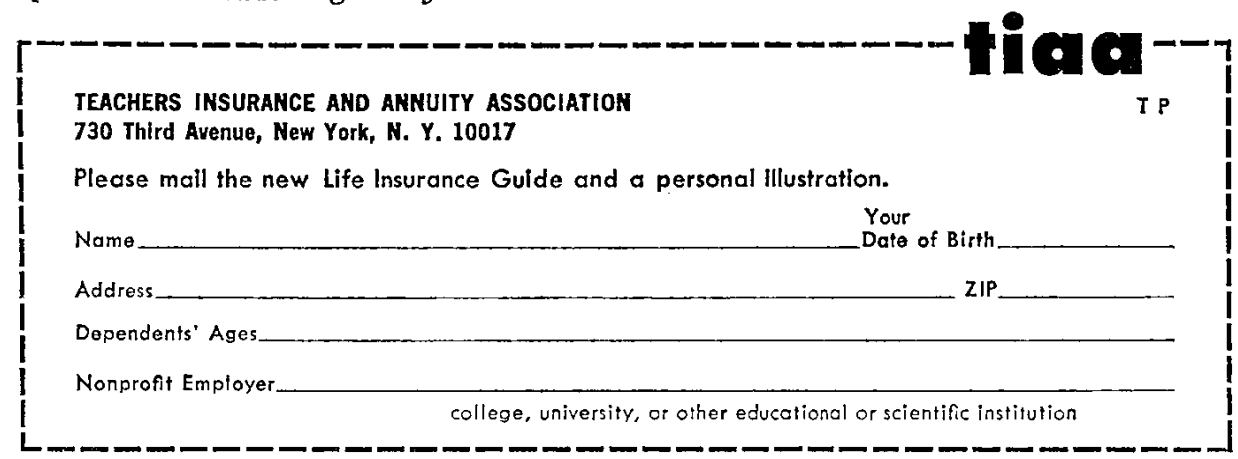




\section{For Members Only_Continued}

VIGNETTE XCVIII. As we begin listing chairmen of junior college English and foreign language departments in PMLA and begin a formal reconsideration of the Ph.D. in English, we should be aware of how closely the present is fulfilling the predictions uttered on many occasions by Warner G. Rice but never more clearly than at the General Session of the annual meeting in 1951. On that occasion he called attention to the development of the junior colleges and community colleges, to the "democratization of education," and to the inappropriateness of the Ph.D. as presently conceived to the actual work that most teachers were doing. "It appears to me that those of us who are in charge of the training of graduate students in Departments of Literature should think purposefully upon these things. Since it is probably not within our power to change the present order, even if we would, we must work within it. Since our colleagues the social scientists and the educationists are likely to gain in authority, it is the part of wisdom to become thoroughly cognizant of their purposes, to acquaint our students with them, and to criticize constructively and with understanding. We have not yet done enough by way of instruction in the art of teaching, especially in that kind of teaching now in demand. We must do more. We are not making the best possible use of such degrees as the Ed.D.-Doctor of Education-which need not be inferior, but which is often dealt with as though it were the last resort of the half-competent. We must dignify, and exploit, this and similar degrees. We must modify our curricula so that those who choose to do so will be encouraged to become proficient in techniques (e.g., television) which, for all we know, may have a decisive influence in all branches of education before another decade has passed. If we fail to do these things, we may still continue to prepare, with reasonable success, Doctors of Philosophy who will replace us, in due time, in the universities. But positions elsewhere, to a marked degree, will be filled by persons trained, largely outside our discipline, by others. It seems to me better to participate with sympathy and vigor in the task of educating a nation than to withdraw or be excluded from the main stream in which this effort flows" (PMLA, February 1952, p. 85). History and the long vacancy lists in English published last March and May bear out prophecies made fifteen years ago. We should honor the seer. Warner G. Rice, born in Aurora, Illinois, took his A.B. from Illinois, and his Ph.D. from Harvard. He was one of the group of tutors appointed in 1924 to initiate the tutorial system at Harvard. At both Illinois and Harvard he came under the influence of the New Humanism of Stuart Sherman, Irving Babbitt, and Paul Elmer More. It may be that their dissatisfaction with Germanic Wissenschaft had more to do than we know with the growth of criticism and our own dissatisfaction with the regime of the Ph.D. In 1929 Warner Rice was appointed associate professor at the University of Michigan. There during the 1930's, while C. C. Fries and Albert Marckwardt were making revolutionary progress in applying linguistics to the teaching of English, Warner Rice was persuading the English department to change its emphasis from literary history and literary backgrounds to close reading and humanistic interpretation. From 1941 to 1953 he gave much of his attention to directing the University of Michigan libraries, but in 1953 he became chairman of the English Department and began trying to express in action and organization the future that he read so accurately. He tried at first to secure movement through the MLA Commission on Trends in Education, which he chaired from 1954 to 1964. In 1960 he and Albert Marckwardt organized (with ACLS support) the prototype institute for high school English teachers. This pattern proved useful to the Commission on English, which held its planning session for the Commission on English institutes at Michigan in the summer of 1961. And the 1962 Commission on English institutes served as models for the first NDEA English institutes. In 1963, when the Association of Departments of English was formed, Warner Rice was the first chairman. There his theme became the managerial revolution-the growing complexity of the operation as departments grow in size. Again, this was not a welcome concept. Warner Rice's gift has been for prophecy and prophets are not often welcomed. It is worth pausing to observe how many people are now acting upon principles Mr. Rice has enunciated so clearly over the years.

JOHNS HOPKINS THREE-YEAR PH.D. IN ENGLISH. In the fall of 1966 Johns Hopkins is introducing a new program. In the first year the student will take three courses and make up any language deficiencies. In the second year he will do two hours a week of supervised teaching and take two seminars. At the end of this year he will take a qualifying oral on his special field and two chronologically adjacent fields. The passing of this examination will result in an M.A. or an M.A. with an invitation to take a Ph.D. in the following year. The last year will be devoted to writing the dissertation and doing two more hours of supervised teaching. A dissertation is defined as a publishable article accompanied by a summary or outline of the larger study to which this article belongs. Exceptional students will be offered full support for a fourth year of free time in which to complete the larger study. The fourth year will be in conjunction with the new Humanities Center being established at Johns Hopkins, with Charles Singleton as its Director. In addition, the Humanities Center plans to invite from ten to twenty young humanistic scholars from other institutions to spend a year of independent, post-doctoral research at Johns Hopkins.

FOUR-YEAR PH.D. IN ENGLISH AT STANFORD. The Department of English, Stanford University, initiated in September 1965 a four-year Ph.D. program: first-year, full-time study devoted to course work in preparation for the written Qualifying Examination based on a reading list and given in September of the second year; second and third years, half-time apprentice teaching and half-time course and seminar work in the special field (the special field and plans for the dissertation are the subject of an oral examination taken no later than March of the third year); fourth year, full-time work on the dissertation. The program moves logically from general knowledge to special field to dissertation. Stanford's four-year Ph.D. can be taken in English literature alone, or in combination with one of the following: American literature, comparative literature, philology, humanities. 


\section{COLUMBIA 2 COLUMBIA}

FABLES OF A JEWISH AESOP

MOSES HADAS, Translator

This charming book is a translation of the animal fables of a famous grammarian, philospher, and Biblical commentator of the twelfth centuryBerechiah ben Natronai ha-Nakdan. These fables were drawn primarily from non-Jewish sources to which he added Hebrew lore. The introduction shows their relation to the Aesopic tradition and to the medieval beast epic. Delightfully illustrated. Introduction by W. T. H. Jackson.

Coming January

\section{THEODORE ROETHKE: An Introduction to the Poetry}

\section{KARL MALKOFF}

The first complete critical study of the poet, winner of the Pulitzer Prize and two National Book Awards, to appear since his death in 1963. This book examines all the poems of each period in Roethke's creative life and relates his work to the thought and poetic theory that preceded it. Just published

\section{NORTHROP FRYE IN MODERN CRITICISM \\ Selected Papers from the English Institute}

\section{MURRAY KRIEGER, Editor}

A collection of essays on one of the most influential literary critics of today - Northrop Frye, author of Anatomy of Criticism, and A Natural Perspective. A paper by Angus Fletcher defends Frye's work and its consequences, while W. K. Wimsatt offers a respectful dissent. An introductory essay by the editor relates Frye to contemporary criticism and to the critical tradition at large. There is a concluding reply to the essays by Frye himself. The book contains in addition the first extensive bibiography of works by and about Mr. Frye.

Just published

$\$ 5.00$

\section{GLOSSARY OF LINGUISTIC TERMINOLOGY}

\section{MARIO PEI}

The most complete and up-to-date survey of the terminology of linguistics. Standard terminology in the areas of descriptive, historical, and geolinguistics are included. Extensive cross references identify synonyms, nearsynonyms, and opposites of terms listed. While this book is suitable for use by the beginner in the field of lingustic studies, it will also be helpful to more advanced students as a fairly large number of more involved and technical terms are included.

Just published

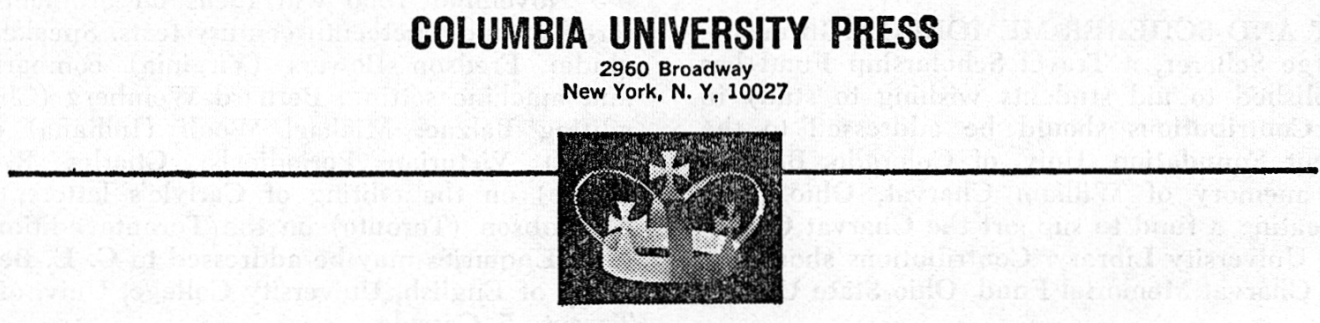

PMLA A-11 


\section{For Members $O_{n} l_{y}-C_{o n t i n u e d}$}

RESEARCH AND TEACHING. Is it worth the effort, or even feasible, to be both teacher and researcher? It is possible to become a teacher-scholar, without having the luck to start as a congenital genius, if one is willing to cultivate at the same time an intelligent love for human learners and a systematic habit of building, upon the best knowledge available, some sort of intellectual contraptions aiming to solve significant problems. The teacher-scholar is scarce, partly because talent is not universal but partly, too, because some grad. uate students who have enough talent to excel remain too self-centered to become good teachers, or too selfindulgent to persist in significant inquiry. The best educational institutions are trying for a "corner" on this scarce type of personnel; and they will compete more and more intensely for it-raising its economic value-as automation and team teaching increase. These innovations are bound to demand a cadre of creative master teachers for every age level from preschool up. The standard of teaching will rise, because education must exploit the human learning capacity more and more efficiently and because students are growing more articulate about their expectations. The creativity demanded will be diverse: within and across departments, and at levels of speculative theory, cultural synthesis, and practical application. Some of the teacher-scholars will have solo parts, others will practice an emerging art of interdisciplinary and even cross-cultural collaboration, but they will all have in common the combining of teaching with research into significant problems. The large, mediocre middle group that has made up the bulk of the teaching profession in the past may be expected to diminish, and even to be supplanted by a great unpopulated gap between the top-flight personnel-the teacher-scholars, teacherscientists, and administrators-and the menial personnel who tend the machines and the routines that remain unmechanized. In the language-teaching sector of the profession, the mass of non-scholar teachers who have patiently corrected the same mispronunciations year after year, without discovering how to head off the causes of the interference, will have no progeny. Their successors will either move up into the predicted élite, or move down among the oilcan people. The same conditions will dispose of the type that has sacrificed teaching to do research on unimportant questions, on the theory that one must publish something or perish. A few geniuses will have research professorships, but the rest must either excel at both teaching and investigation or accept tasks such as elaborating instructional materials, analogous to the engineering graduates who make a life career as draftsmen. If the stakes are rising, as I think, there is no time for the humdrum but we must make time for imaginative thought.

(Howard Nostrand, Univ, of Washington)

CHARVAT AND SCHERER MEMORIALS. In memory of George Scherer, a Travel Scholarship Fund has been established to aid students wishing to study in Germany. Contributions should be addressed to the Development Foundation, Univ. of Colorado, Boulder 80302. In memory of William Charvat, Ohio State Univ. is creating a fund to support the Charvat Collection in the University Library. Contributions should be sent to the Charvat Memorial Fund, Ohio State University.
VIGNETTE XCVIV. Don Cameron Allen, Second Vice President of the MLA, was born in St. Louis and took his A.B. and Ph.D. from the University of Illinois. Before coming to Johns Hopkins in 1942, he taught at Illinois, Purdue, Illinois Wesleyan, Washington State, and Duke. His scholarly editions and The Star-Crossed Renaissance (1941) set a high standard for historical and textual scholarship. ELH (English Literary Histo$r y$ ), eight years old when Allen came to Hopkins, had likewise achieved an enviable reputation for sound scholarship. But by the 1950's both Don Allen and $E L H$ had come to wear a different complexion. Under his editorship $E L H$ had moved to become internationally recognized for its interpretive criticism, and Don Allen's own scholarship had turned to sensitive critical analysis: The Harmonious Vision (1954), Image and Meaning (1960), and Doubt's Boundless Sea (1964), to name only three. His interests range from the history of Renaissance ideas to the nature of poetry, as revealed in the remarkable introduction to Four Poets on Poetry (1959); from Sir William Cornwallis to Dame Edith Sitwell; from the "henological" proof for the existence of God to the "runaway Eros" of Greek pastoral poetry. More than forty Ph.D.'s attest to his success as a graduate teacher, and scores of other younger scholars have profited by his thoughtful editorial criticism of their writings. Remarkably, despite his success within the English establishment, Don Allen has come to question the pattern. Recognizing demands of a new era, he has agreed to take a lead in the reevaluation of doctoral study in English. Better than most of us, he recognizes that reformation must precede a renascence -that if changes are to come, they had better come from within rather than from without. The MLA was founded at Johns Hopkins and is still incorporated in the State of Maryland. The English Department at Johns Hopkins is still our official home address. Graduate study and scholarship in language and literature are still our raison d'être. What more need be said?

CLEMENS BRENTANO. The Freie Deutsche Hochstift, 6 Frankfurt a/Main, Grosser Hirschgraben 23-25, is preparing a historical-critical edition of the complete works and letters of Clemens Brentano, for which all available manuscripts will be used. Owners of such manuscripts and letters are asked to send a short description to the address indicated. Information about letters addressed to Clemens Brentano and other evidence of the poet's life would also be welcome. Other information as to his relatives and his friends, about destroyed or missing manuscripts and manuscripts in other collections, whether public or private, would also be appreciated.

CONFERENCE ON EDITORIAL PROBLEMS. A conference to be held at the University of Toronto on 4-5 November 1966 will focus on problems encountered in mid-nineteenth century texts. Speakers will include: Fredson Bowers (Virginia) comparing hand and machine setting; Bernard Weinberg (Chicago) on editing Balzac; Michael Woolf (Indiana) discussing British Victorian Periodicals; Charles R. Sanders (Duke) on the editing of Carlyle's letters; and John M. Robson (Toronto) on the Toronto edition of J. S. Mill. Enquiries may be addressed to G. E. Bentley, Jr., Dept. of English, University College, Univ, of Toronto, Toronto 5, Canada. 


\title{
A MODERN SERIES IN FOREIGN LANGUAGES ...to develop skill in speaking, reading, and writing
}

\section{DEUTSCH, ERSTES BUCH}

By Hugo Mueller, Ph.D.

Consists of phonology section, 24 lessons, complete reference grammar and vocabulary. $\$ 4.95$ Teacher's Key: \$1.00 Tests: $\$ 1.00$; Key to Tests: $50 \phi$ RECORDINGS:

15 Magnetic Tapes, $\$ 103.00$ net

\section{ESPAÑOL, PRIMER CURSO, PART I}

By Mariano E. Gowland

First 12 lessons of the first course. Includes sections on phonology, grammar, and vocabulary.

$\$ 3.95$

RECORDINGS:

8 Magnetic Tapes, $\$ 56.00$ net

\section{FRANÇAIS, PREMIER COURS}

By Leon Dostert, A.M., Litf.D.

An introductory course. Consists of section on phonology, 24 lessons each built on an everyday dialogue, and complete reference grammar and vocabulary.

$\$ 4.95$

RECORDINGS:

14 Magnetic Tapes, $\$ 98.00$ net

\section{RUSSIAN LANGUAGE, FIRST BOOK, PART I}

By Mariana Poltoratzky, Ph.D., and Michael Zarechnak, M.A.

Contains a section on phonology, 12 lessons, a brief but competent reference grammar, a unit on Russian caligraphy, and vocabularies. $\$ 4.50$ RECORDINGS:

8 Magnetic Tapes, $\$ 72.00$ net

\section{GERMAN \\ DEUTSCH, ZWEITES BUCH \\ By Hugo Mueller, Ph.D.}

Unique text for the intermediate level. Gives systematic information on cultural and anthropological aspects of present-day Germany $\$ 4.25$

RECORDINGS

18 Magnetic Tapes, $\$ 126.00$ net

\section{W SPANISH \\ ESPAÑOL, PRIMER CURSO, PART II \\ By Mariano E. Gowland}

Contains final 12 lessons of first course, verb tables, conjugation charts, and vocabulary. $\$ 4.35$ RECORDINGS

7 Magnetic Tapes, $\$ 49.00$ net

\section{FRENCH}

\section{FRANÇAIS, COURS MOYEN,} Civilisation

By Leon Dosfert, A.M., Liff.D. with Jacqueline Lindenfeld, L.esL.

Presents French life and culture through interesting narratives.

Grammar summarizes points

illustrated in lessons. \$4.95 Teacher's Key: $\$ 1.00$

RECORDINGS:

24 Magnetic Tapes, $\$ 168.00$ net

\section{RUSSIAN \\ RUSSIAN LANGUAGE, FIRST BOOK, PART II \\ By Mariana Poltoratzky, Ph.D., and Michael Zarechnak, M.A.}

Includes final 12 lessons to first course, a complete reference grammar, and vocabularies.

\section{RECORDINGS:}

11 Magnetic Tapes, $\$ 81.00$ net

\author{
DEUTSCH, DRITTES BUCH \\ By Hugo Mueller, Ph.D.
}

An advanced course. Equips students with comprehension of various levels of style in spoken and written German. $\quad \$ 5.00$ RECORDINGS:

11 Magnetic Tapes, $\$ 77.00$ net

\section{ESPAÑOL, SEGUNDO CURSO}

By Mariano E. Gowland

Includes articles from Spanishlanguage newspapers and periodicals. Emphasizes civilization and culture of Spain and Latin America.

$\$ 6.50$ RECORDINGS

13 Magnetic Tapes, $\$ 91.00$ net

FRANÇAIS, COURS

AVANCÉ, Styles Littéraires

By Leon Dosfert, A.M., Litt.D., with Monique Decaux, L.esL.

24 lessons introduce reader to major types of French Literature and Style of 19th and 20th centuries. Questions, exercises, and list of proverbs are also included with lessons. $\$ 5.00$

\section{RUSSIAN LANGUAGE, SECOND BOOK, RUSSIAN CULTURE}

By Mariana Poltoratzky, Ph.D.

Informative and exciting picture of Russian culture and history through narrative selections. Includes grammatical notes and reviews.

$\$ 6.50$ RECORDINGS:

20 Magnetic Tapes, $\$ 140.00$ net

\section{AUDIO-VISUAL AIDS}

RECORDINGS: All tapes were made by native speakers. Student is exposed to language as actually spoken.
WALL CHARTS: All introductory courses use same 12, full-color, $27 \times 36$ inch wall charts, mounted on single roller. 


\section{For Members $O_{n} l_{y}-C_{o n t i n u e d}$}

MLA CHARTER FLIGHTS. The 1966 charter flights consisted of four jets totaling 720 seats. Over 990 MLA members were booked on these flights, but 362 cancellations and the removal of $\mathbf{5 0}$ members, who did not meet eligibility requirements, made it necessary to reduce the 7 July flight to half a charter leaving a total of 630 seats. There were about 350 inquiries by letter of which $15 \%$ were booked, and 53 requests for one-way seats resulted, through matching, in 12 additional bookings.

For the summer of 1967 five DC-8 jets have been chartered with a 180-passenger capacity each. Four of the flights $(\$ 285)$ are scheduled for New York-Brussels or Paris-New York, and one flight (\$275) is scheduled for New York-London-New York. The schedule below is tentative.

\begin{tabular}{|c|c|c|c|}
\hline & $\begin{array}{l}\text { Leaves } \\
\text { New York }\end{array}$ & $\begin{array}{l}\text { Returns } \\
\text { New York }\end{array}$ & Destination \\
\hline IT & $\begin{aligned} 8 & \text { June } \\
15 & \text { June }\end{aligned}$ & $\begin{array}{ll}8 & \text { Sept. } \\
4 & \text { Sept. }\end{array}$ & $\begin{array}{l}\text { Brussels or Paris } \\
\text { Brussels or Paris }\end{array}$ \\
\hline & 24 June & 27 Aug. & Brussels or $\mathrm{Paris}$ \\
\hline v & $\begin{array}{l}29 \text { June } \\
1 \text { Aug. }\end{array}$ & $\begin{array}{l}30 \text { Aug. } \\
11 \text { Sept. }\end{array}$ & $\begin{array}{c}\text { London } \\
\text { Brussels or Paris }\end{array}$ \\
\hline
\end{tabular}

Only those members will be eligible for MLA charter flights whose names appear in the September 1966 printed list of members (see PMLA, March 1966, p. A6). Each MLA member will receive an application form this fall with final information on dates and flights. All inquiries should be directed to our authorized travel representatives: Air-Res, 866 United Nations Plaza, New York, N.Y. 10017; telephone (212) 752-6671.

SHORT TITLE CATALOGUE, 1641-1700. Donald Wing's monumental 3-volume index published by the Index Committee of the MLA (formerly the Index Society) has very nearly run out of print. In order to continue to make it available, the Committee is reprinting 200 copies of each volume by photo-offset. Unfortunately the cost of this reprinting will raise the cost of individual volumes to $\$ 40$ and the set to $\$ 120.00$.

ACLS TRAVEL GRANTS. The ACLS has funds from which to make travel grants for persons participating in international congresses. Since the funds are limited, applicants must be sponsored and recommended by their member associations. The MLA Executive Council in 1958 established a procedure for recommending applicants. Only persons who are to read papers or to take some official part in a congress will be eligible for such awards. In the case of major congresses held triennially or at longer intervals as many as six awards, covering tourist class, may be made. Congresses must be of truly international participation. Applications should be received in triplicate (together with supporting letters of recommendation) not later than 15 February of the year in which the congress is held.
NEW JOURNALS. The Chaucer Review, ed. R. W. Frank, Jr., and Edmund Reiss (Pennsylvania State Univ.), a quarterly journal devoted to Chaucer and his age began publication in the summer of 1966. In addition to articles, it will publish an annual Chaucer bibliography. Subscription $\$ \mathbf{5 . 5 0}$. MSS should be sent to the editors, 246 Sparks Building, The Pennsylvania State University, University Park 16802, with return postage. Arcadia: Zeitschrift für vergleichende Literaturwissenschaft, a new periodical of comparative literary science, begins publication in 1966. It will be devoted to present-day comparative methods in the his. tory and science of literature. Horst Rüdiger (Bonn), Roger Bauer (Saarbrücken-Strassburg), Erik Lunding (Aarhus), and Oskar Seidlin (Ohio State), edd. Subscription DM 42 for three issues a year, Verlag Walter de Gruyter \& Co., Berlin. Contributions will be printed in German, English, or French. Contributions in English should be sent to the American editor, Oskar Seidlin, Dept. of German, Ohio State Univ., Columbus 43210. Die Diagonale, Halbjahreszeitschrift für Dichtung und Kritik, ed. Joachim Seyppel, began publication in the spring of 1966. It is especially concerned with German-American literature. Subscription $\$ 2.00$, F. A. Herbig, Verlagsbuchhandlung, Berlin. JEL, the Journal of English Linguistics, ed. Robert A. Peters (Western Washington State Coll.), will begin publication in 1967. It will deal with all dialects and world varieties of modern and older English. Subscription $\$ 3.00$ for a single volume. MSS (conforming to the MLA Style Sheet) and books for review should be sent to the editor, Dept. of English, Western Washington State College, Bellingham, Washington 98225. Pacific Coast Philology, ed. William Matthews (UCLA), began publication in April 1966. It is issued free to members of the PAPC, whose scholarly interests it represents. Copies are available to non-members $(\$ 1.50)$ from the Secretary-Treasurer of the PAPC, R. S. Meyerstein, Dept. of Foreign Languages, San Fernando Valley State College, Northridge, Calif. 91324. Computers and the Humanities: A Newsletter, ed. Joseph Raben (Queens Coll.), devoted to aspects of literature, musicology, art history, folklore, and those aspects of social sciences and linguistics having a humanistic bent, will appear bi-monthly. Subscription is $\$ 4.00$ a year for five issues from Joseph Raben, Dept. of English, Queens College, Flushing, New York 11367. The Afro-Asian Theatre Bulletin, ed. Fredric M. Litto (Kansas), will be published in October and February each year at the University of Kansas for those interested in producing, translating, or writing articles on Afro-Asian drama. It may be obtained free upon request from the Dept. of Speech and Drama, University of Kansas, Lawrence 66044. The Journal of the Chinese Language Association, ed. Adele Rickett (Pennsylvania), replacing the Association's Newsletter, began publication in February 1966. The editorial mailing address is Oriental Studies Dept., Box 25, Bennett Hall, University of Pennsylvania, Philadelphia 19104. 


\section{Readers and Anthologies from SCOTT, FORESMAN}

\section{LITERATURE FOR UNDERSTANDING}

B. BERNARD COHEN, Wichita State University

Familiar and refreshingly different products of the creative imagination are all included in this anthology, which provides the basic literary texts for reading, for class discussion, and for analytical essays. Poetry selections range from Spenser and Shakespeare to Eliot and Stevens, and include work by Richard Eberhart, Robert Fitzgerald, Karl Shapiro, Howard Nemerov, and Philip Booth. In fiction, the selections include "Mateo Falcone" by Prosper Merimée (newly translated by Professor and Mrs. Cohen); two stories by Franz Kafka; "Rich People" by Nancy Hale; and stories by J. F. Powers, George P. Elliott, and Dan Jacobson. The drama selection in. cludes tragedies by Sophocles and Shakespeare, a realistic drama by Ibsen, and a comedy by Thornton Wilder. 1966, Softbound, 544 pages, $\$ 3.25$

\section{WORKING FOR LITERARY UNDERSTANDING}

\section{A Guide to Critical Reading}

\section{B. BERNARD COHEN}

Keyed to the selections in Literature for Understanding, this study guide offers the student extensive practice in literary analysis. Each of the three sections (poetry, fiction, drama) has its own introduction, which presents terminology and definitions, stresses particular characteristics of each genre, and interrelates the genres. Following each introduction, a series of exercises leads the student to a fuller understanding of selected works and relates these works to their genre. There is ample writing space for student responses, which become, in effect, miniature compositions. Many of the exercises culminate by suggesting theme topics. 1966, Softbound, 304 pages, $\$ 2.25$

\section{WRITING ABOUT LITERATURE}

\section{B. BERNARD COHEN}

This text offers the student personal advice about the problems involved in composing papers on literary works: the basic steps in literary interpretation, the relation of idea to structure, solid. ity of content, organization, and style. Included are an extensive glossary of literary terms, suggestions for analyzing fiction and poetry, and a theme grading chart. 1966, Softbound, 191 pages, $\$ 2.25$

\section{BETTER READING 2: LITERATURE, Fourth Edition}

WALTER BLAIR, The University of Chicago JOHN GERBER and EUGENE GARBER, both of the University of Iowa

This Fourth Edition should prove even more effective than its predecessors in helping students to increase their skill in understanding and evaluating fiction, drama, and poetry. One of the most important new features of this revision is its Part Three, a casebook on "Heart of Darkness," which provides basic writings in psychology, philosophy, politics, etc., from which the student can fashion his own critical opinions. Included among the new selections are Eudora Welty's $A$ Curtain of Green and Edward Albee's The American Dream. 1966, 848 pages, $\$ 6.75$

\section{COLLEGE READING AND COLLEGE WRITING}

\section{WILLOUGHBY JOHNSON, University of Missouri, THOMAS M. DAVIS, Southern Illinois University}

The seventy-five essays in this anthology are directly related to the student's experience; they relate to his past, his present, and his future. At the same time, they illustrate various rhetorical devices and provide examples of effective organization, logical reasoning, and clear expression. Study questions and theme topics accompanying the essays help the student to develop his skills in reading and writing. Background on rhetorical stance, tone, and style is provided in the introduction. 1966, Softbound, 496 pages, $\$ 4.00$

\section{IDENTITY: Stories for This Generation}

\section{KATHERINE HONDIUS, City College of San Francisco}

This anthology of seventeen modern American short stories deals with the intellectual and emotional problems of late adolescence and young adulthood. The selections represent various narrative types to promote an understanding of short story methods, techniques, and purposes. Twenty-nine general questions for story analysis and brief biographies of the authors follow the stories. 1966, Softbound, 284 pages, \$2.95

\section{SCOTT, FORESMAN AND COMPANY - College Division}


A student is about to dial the phone in his dorm room. He's going to use it to study French by calling the Learning Lab. At the same time other students will be dialing lessons in Biology, Government, Speech . . . any subject the university has scheduled for that period. Through the telephone, universities can extend their Learning Lab facilities economically to every dormitory room, so students can take full advantage of a university's opportunities.

This use of the telephone as a learning tool, in addition to its everyday function, is just a beginning. Soon, a student will be able to connect with a computer, put a problem to it, and receive information back in the most convenient form . . . voice or teletypewriter . . . even as a video image.

This is one more way we are working to improve communications to meet the future needs of students, faculty and administration. Many of these communications systems-Tele-Lecture service (two-way amplified phone calls), Data-Phone* service, and remote blackboard projection-are available now. Find out what you can do to benefit from them by talking with your Bell Telephone Communications Consultant.

\section{Dial 3621 for French III}

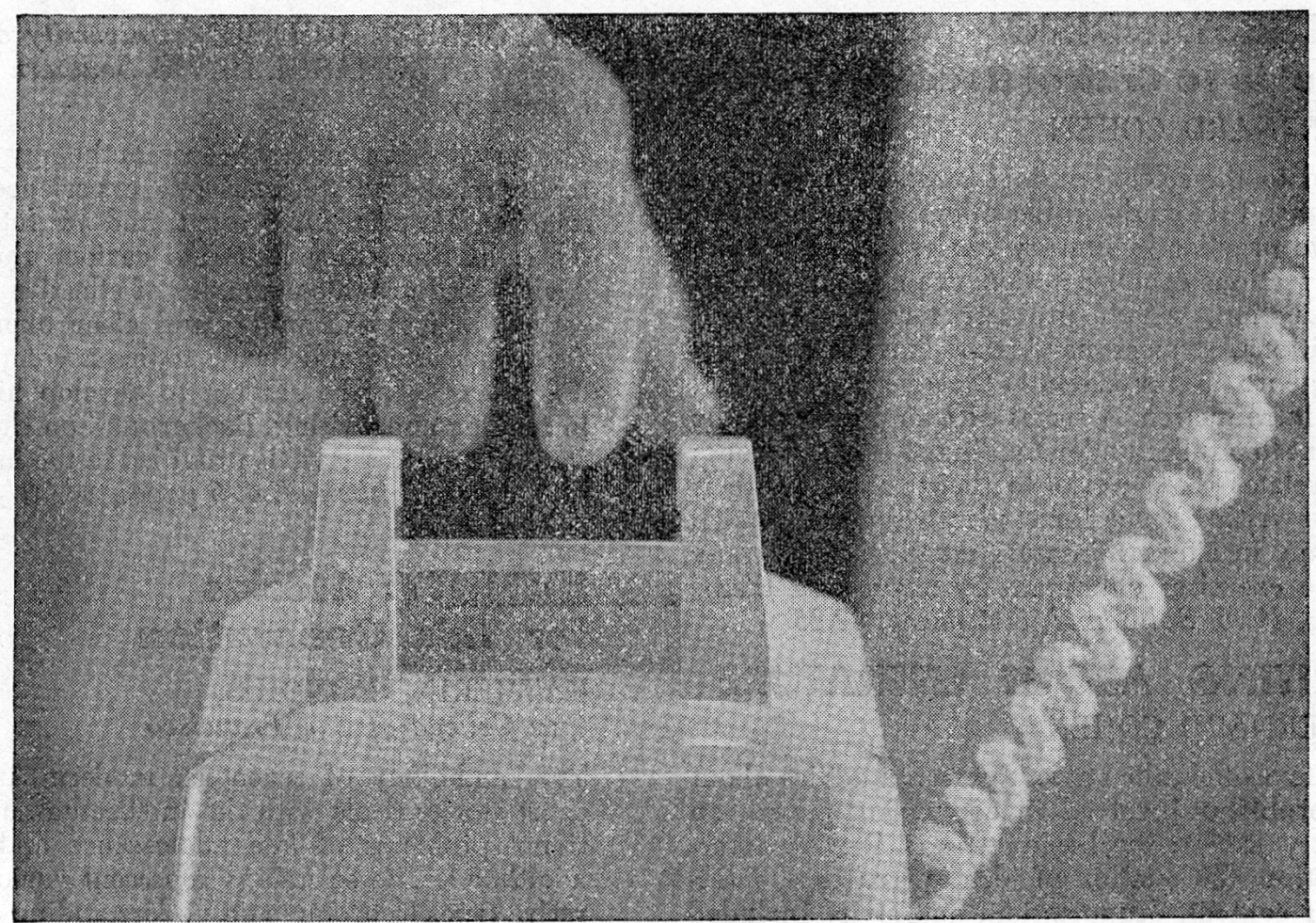

*Service mark of the Bell System 


\section{THE HERO \\ WITH \\ THE \\ PRIVATE \\ PARTS \\ ae \\ Essays by \\ Andrew Lytle}

Foreword by

Allen Tate
THIS Is THE first collection of the non-fictional writing of Andrew Lytle, distinguished editor of the Sewanee Review and noted critic, novelist, and literary scholar.

The Hero with the Private Parts contains essays on the stories of Crane and Hemingway, the novels of Flaubert, Faulkner, and Caroline Gordon, and on the author's own novel, The Velvet Horn. Other selections are on literary theory, cultural history, and the art of fiction.

Lytle's criticism has the striking quality of presenting a close analysis of the work under study, while at the same time providing an overview of the creative process which informs the particular work.

This volume demonstrates the profound and incisive thought and the extensive knowledge of a leading student of American letters and culture.

$\$ 6.00$

\section{SOUTHERN LITERARY STUDIES}

is a continuing series, to include critical and biographical studies, thematic analyses, literary history, and the original non-fictional work of Southern writers.

Forthcoming volumes in the series include a biography of Joel Chandler Harris, an analysis of Southern literary criticism in the twentieth century, a historical account of the short story in the South from Poe to Faulkner, and other critical studies by such scholars as Robert D. Jacobs, Edd Winfield Parks, George Garrett and C. Hugh Holman.

General editor of Southern Literary Studies is Louis D. Rubin, Jr., Hollins College, Virginia.

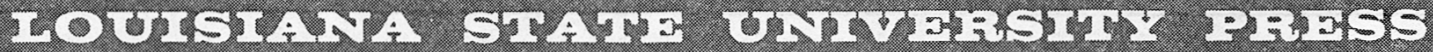




\section{PAUL KLUCKHOHN:}

Die Auffassung der Liebe in der Literatur des 18. Jahrhunderts und in der deutschen

Romantik

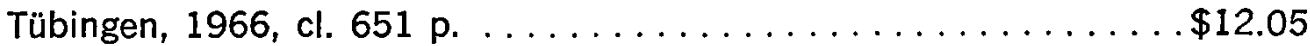

Reprint of the 1931 classic, enlarged with an index of names.

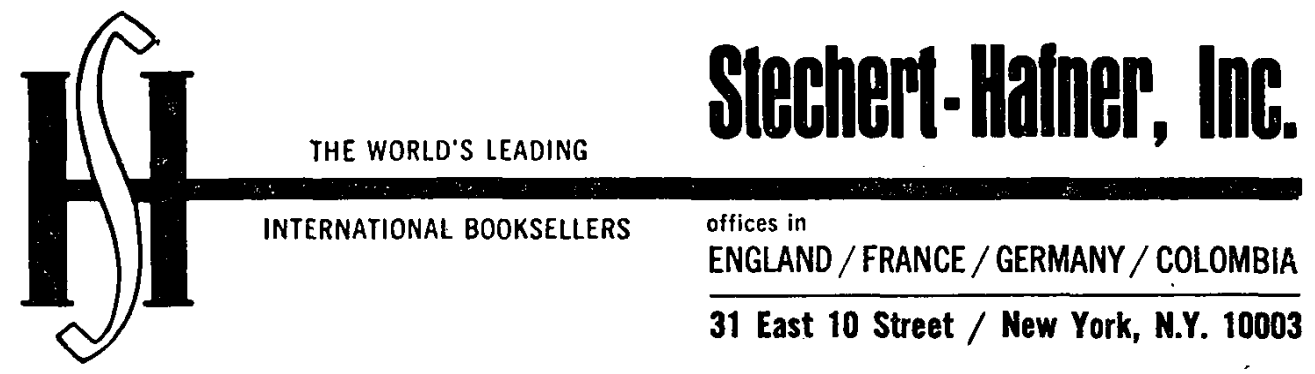

Published by M L A Distrbuted by New York Unibersity Preses

Congreve's Plays on the Eighteenth-Century Stage, by Emmett L. Avery (1951). $\$ 3.75$

The Rediscovery of Sir John Mandeville, by Josephine W. Bennett (1954). $\$ 6.70$

The Consecutive Subjunctive in Old English, by Morgan Callaway, Jr. (1933). \$1.50

The Sources of the Text of Quevedo's Politica de Dios, by James O. Crosby (1959). $\$ 3.00$

Peter Idley's Instructions to His Son, edited by Charlotte D'Evelyn (1935). \$2.50

The Passion Play of Lucerne: An Historical and Critical Introduction, by Blakemore M. Evans (1943). $\$ 3.50$

Répertoire des lexiques du vieux français, by Raphael Levy (1937). $\$ 2.00$

Old English Glosses: A Collection, by Herbert Dean Meritt (1945). $\$ 2.00$

The Writings of Arthur Hallam, edited by T. H. Vail Motter (1943). $\$ 3.50$

Eight American Authors: A Review of Research and Criticism, edited by Floyd Stovall (1956). $\$ 4.00$

Letters of Ludwig Tieck, Hitherto Unpublished, 1792-1853, edited by Edwin H. Zeydel, Percy Matenko, and R. H. Fife (1937). $\$ 5.00$

ORDER fROM New York University Press - 32 Washington Place - New York City 10003 


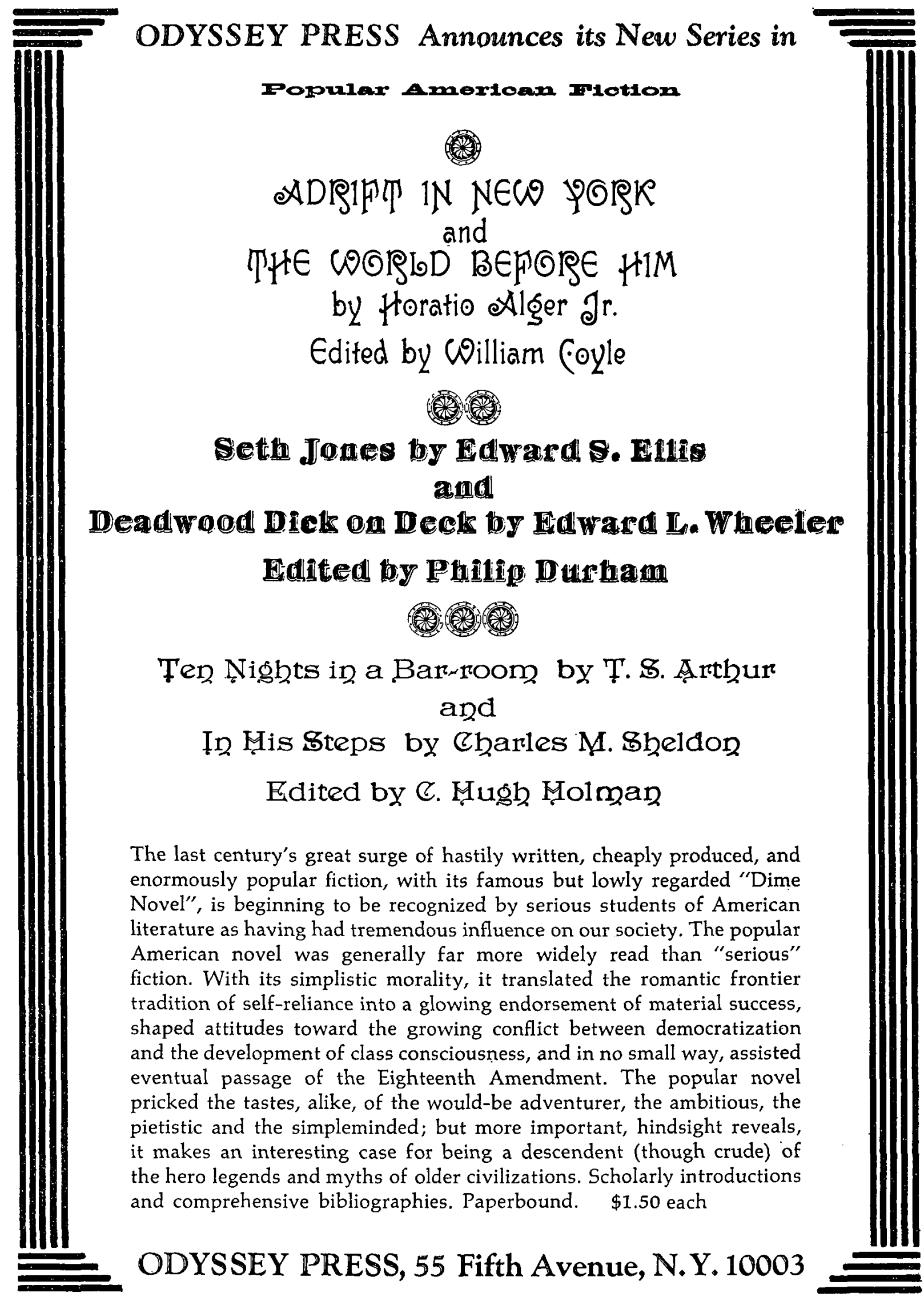




\section{TWO IMP0RTANT NOTICES TO LIBRARIES AND SCHOOLS ORDERING FOREIGN BOOKS}

I. As America's largest French booksellers, we have been deluged with requests-not only for books in French-but for those in other foreign languages as well. We are, therefore, for the first time, formally accepting orders for books in other foreign languages, especially SPANISH, GERMAN, ITALIAN, and BRITISH and other European titles. While French books are almost always available from stock and immediately shipped, all others must be specially-imported and will be available within four to six weeks after your order is received. If the response to this experiment is positive, we shall stock important foreign books on a regular basis. Meanwhile, we welcome your comments and suggestions.

II. Free-118 Page Catalog and Supplement of Imported French Books

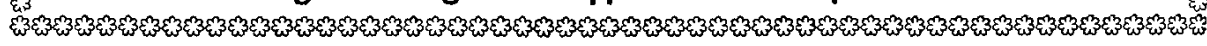

Two years ago, we published the most complete catalog of imported French books ever compiled in the United States. Entitled "French Books-Kindergarten through College," this catalog is the result of one year of arduous work by five specialists on our staff and lists more than 4,000 titles. The Supplement, published last year, is now available.

Our catalogs are divided into six sections, covering just about every subject in the French curriculum, from the alphabet through advanced and graduate studies. Included are selections for Elementary Schools, Junior High Schools, High Schools, Colleges, Advanced Studies and Libraries. We shall be happy to send you these catalogs on request.

\section{FRENCH \& EUROPEAN PUBLICATIONS, INC.}

Rockefeller Center 610 Fifth Avenue

\section{French Building}

New York, New York 10020

\section{America's leading French booksellers}

serving universities, high schools, elementary schools, libraries, bookstores, institutions and the teaching profession since 1928 


\section{Orfond uniug \\ A Practical Rhetoric of Expository Prose}

By Thomas S. Kane and Leonard J. Peters, University of Connecticut, Waterbury Branch

$1966 \quad 608$ pp. $\$ 5.00$

\section{Classical Rhetoric for the Modern Student}

By Edward P. J. Corbetr, Ohio State University

$1965 \quad 608$ pp. $\quad \$ 5.00$

\section{Essays on Rhetoric}

Edited by DudLey BaILey, University of Nebraska

$1965 \quad 320$ pp. paper $\$ 2.95$

\section{Poetry_From Statement to Meaning}

By Jerome Beaty, Emory University, and William H. Matchett, University of Washington

$1965 \quad 352$ pp. $\$ 4.50$

\section{Language and Culture}

By Herbert Landar, California State College at Los Angeles 1966288 pp. illus. cloth $\$ 6.50$ paper $\$ 3.75$

\section{The Modern Tradition:}

Backgrounds of Modern Literature

Edited by Richard Ellmann, Northwestern University, and Charles Femelson, JR., Yale University $1965 \quad 968$ pp. $\$ 9.75$

\section{A la recherche de Paris: A French Cultural Reader}

Edited by Rouben Cholakin, Hamilton College, and L. A. Uffenbeck, University of Wisconsin $1966224 \mathrm{pp}$. illus. paper $\$ 2.75$

\section{The Language Laboratory and Modern Language Teaching Revised Edition}

By Edward M. STack, North Carolina State University 


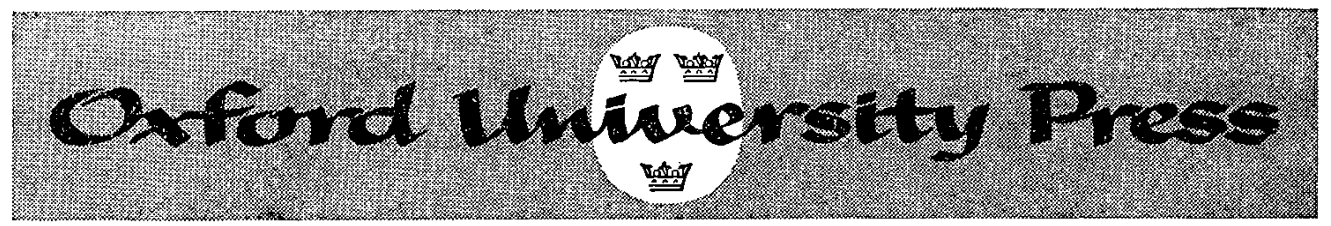

\section{A World Elsewhere}

\section{The Place of Style in American Literature}

By Richard PoIrier, Rutgers University. Marking the arrival of a major American critic, A WORLD ELSEWHERE offers entirely new possibilities for the understanding of American literature. Its originality consists in Mr. Poirier's emphasis on language. By stylistic and critical examinations of Cooper, Emerson, Hawthorne, Melville, Twain, and many other writers, Mr. Poirier discovers a persistent conflict in American literature between environment as a construct of language and environment as a social-historical force exerting an opposing power over that language.

$\$ 5.75$

\section{Nil}

\section{Episodes in the Literary Conquest of Void During the Nineteenth Century}

By Ronert Martin Adams, Cornell University. The sense of vacancy and emptiness is a major characteristic of the modern sensibility. The idea of Nothing, the blank, the void, holds an intense fascination for many of today's writers, film makers, artists, and even musicians. The many approaches and experiments with the topic made in the course of the nineteenth century are the central objects of Professor Adams's study. Since French writers figured prominently in the first critical experiments with the concept of Nothing, Flaubert, Baudelaire, and Mallarmé are examined in detail. The works of Gogol, Leopardi, Poe, and Melville are also fully covered.

$\$ 6.00$

\section{The Strings Are False}

\section{An Unfinished Autobiography}

By Louis MACNeICE. Early in the last war Louis MacNeice left a manuscript for safe keeping at Oxford with his friend Professor E. R. Dodds. He contemplated publishing it eventually, but seems afterwards to have forgotten about it. Professor Dodds has prepared it for publication, and has added a further autobiographical fragment, from a book which MacNeice embarked on much later in life but never completed. THE STRINGS ARE FALSE is a living, sensitive, and very honest self-portrait-and an important literary document.

$\$ 6.00$

\section{Collected Poems of Louis MacNeice}

Edited by E. R. Dopds, Oxford University. This volume contains all the poetry written between 1925 and 1948 that Louis MacNeice wished to preserve, and all the poems from the five volumes published between 1949 and 1963, the year of the poet's death. The volume also contains some new material which has never been published in book form before.

November. $\$ 9.75$

\section{Oxford University Press / New York}




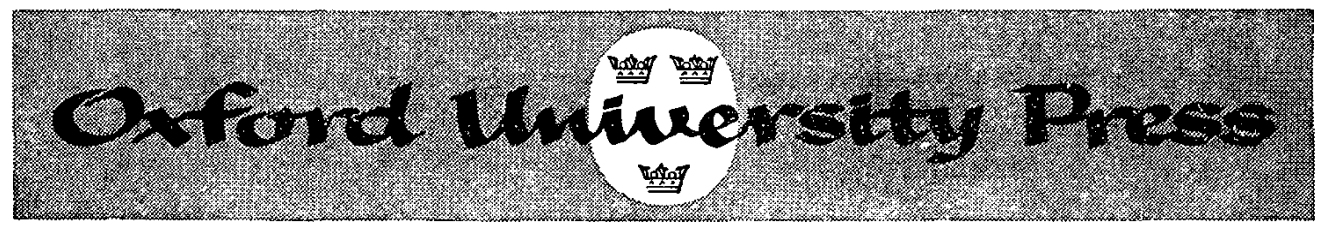

\section{The Complete Poems of Thomas Gray}

\section{English, Latin and Greek}

Edited by H. W. StarR and J. R. Hendrickson, both of Temple University, Philadelphia. This edition is the first to include all Gray's verse, English, Latin and Greek. The texts have been established by collation of all known MSS, early printed versions, printer's directions and revisions in Gray's correspondence. All important textual variants are contained in a critical apparatus. The commentary discusses obscurities in the text, includes all Gray's mottoes, marginal notes and footnotes, and gives translations from languages other than English. This is the first edition to include literal translations of all the Latin and Greek poems. (Oxford English Texts)

$\$ 8.00$

\section{The Esdaile Poems}

\section{Early Minor Poems from the "Esdaile Notebook"}

By Percy Bysshe Sheleey; edited by Neville Rogers, Ohio University at Athens. This is the first edited text of Shelley's youthful "Esdaile Poems." Until recently these littleknown pieces, which reveal the beginnings of what Professor Rogers calls "Shelley's wonderful, fluent, classical syntax," were owned by the descendants of Shelley's first wife, Harriet, to whom several of the poems pay touching tribute. The textual methods, evolved by the editor during his long study of Shelley's work, are explained in the introduction and will be of interest to all those who work with manuscripts.

1 plate. $\$ 4.80$

\section{Richard II (1597) \\ I Henry IV (1598)}

Edited by Charlton Hinman, University of Kansas. Reproductions of the early quarto editions of Shakespeare are rare, and the present series was undertaken to satisfy a long-felt need for a complete set of reliable reproductions. It was begun in 1939 under the direction of the late Sir Walter Greg, who brought it about halfway to completion. Work on the project was resumed under the direction of Charlton Hinman, who has now prepared No. 13 Richard $I I$ and No. 14 I Henry $I V$. The books have introductions and marginal line numberings to accompany the collotype-facsimile texts. (Shakespeare Quarto Facsimiles) Each, $\$ 5.20$

\section{Letters of Laurance Sterne}

Edited by Lewis Perry Curtis, Yale University. This reprint of Sterne's characteristic and revealing letters, with full commentary, has been needed since the work went out of print in 1945. Professor Curtis prints nearly 240 letters together with the Journal to Eliza and Memoirs of the Life and Family of the late Rev. Mr. Laurence Sterne, and includes a number of letters from Sterne's correspondents and members of his family. He also gives reasons for omitting 47 letters which he regards as forgeries by William Combe.

8 plates. $\$ 8.80$ 


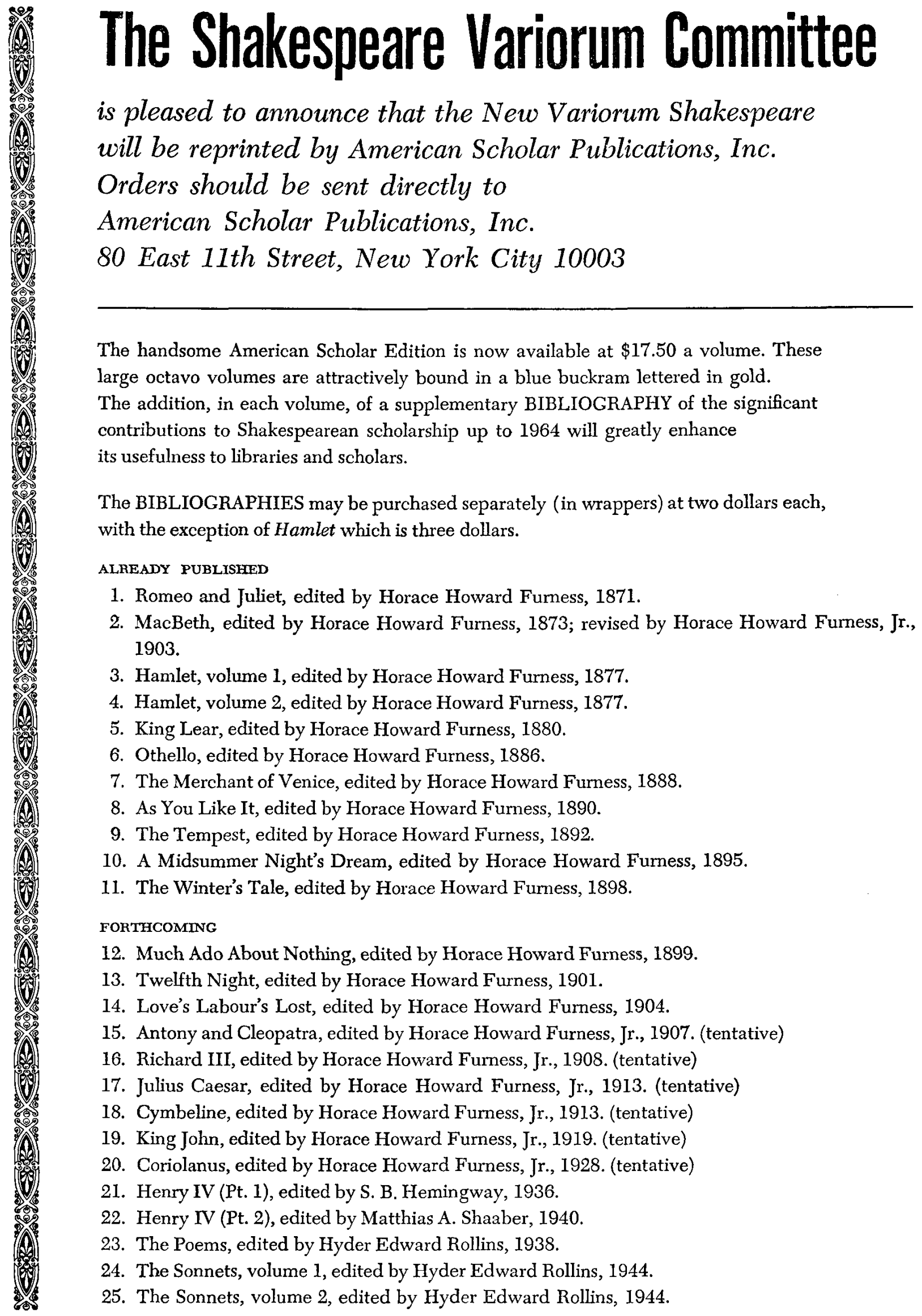




\section{The University of Tulsa Department of English Monograph Series}

General Editors: Thomas F. Staley and Winston Weathers.

1. THE CELTIC BULL: Essays on James Joyce's Ulysses. Edited by Judy-Lynn Benjamin and written by students of Hunter College. A special hardcover edition of 300 numbered copies will be offered at $\$ 3.25$ per volume. Copies of the softcover edition will be priced at $\$ 2.25$ each. Available September, 1966.

\section{FORTHCOMING}

2. STUDIES IN ENGLISH IN HONOR OF PROFESSOR FRANKLIN J. EIKENBERRY bY his former students. Among the contributors will be Carter Revard, Washington University of St. Lovis; Robert Stevick, University of Washington; Norman Hinton, St. Louis University.

3. ESSAYS ON JONATHAN SWIFT. By members of the University of Tulsa Department of English. Papers prepared for the tercentennary of Swift's birth.

4. THE EPIC EXPERIENCE. Essays in World Literature. By Winston Weathers. Papers on Goethe, Gogol, Lagerkvist, et alia.

\section{OTHER UNIVERSITY OF TULSA PUBLICATIONS:}

The James Joyce Quarterly, now in its fourth year. Edited by Thomas F. Staley. Nimrod: A Literary Review, now in its eleventh year of continuous publication.

Each monograph is priced between $\$ 2.25$ and $\$ 3.00$. Subscribers to the series will pay only $\$ 2.00$ for each monograph.

Name:

Address: $\ldots \ldots \ldots \ldots \ldots \ldots \ldots \ldots \ldots \ldots \ldots \ldots \ldots$ Zip $\ldots \ldots \ldots \ldots$

I wish to subscribe to the entire series (to subscribers, first four monographs, $\$ 8.00$ )

I wish to purchase the first monograph, THE CELTIC BULLI I

$\$ 2.25$

$\$ 3.25$

Amount enclosed

Please bill me

Send to: The Monograph Series, The Depariment of English, The University of Tulsa, Tulsa, Oklahoma 74104. 


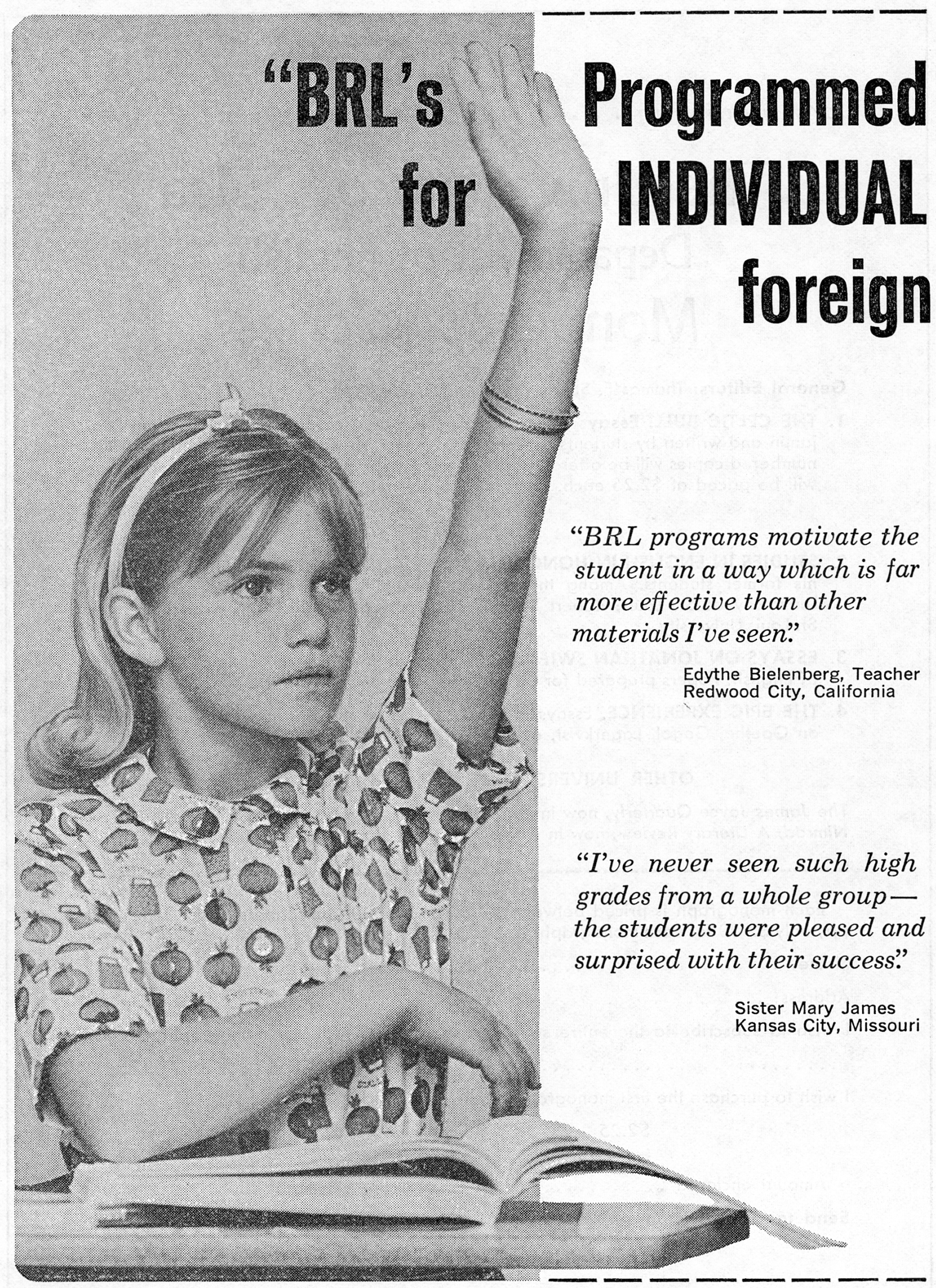




\section{Courses are excellent}

learning of

languages"

These are but a few of the enthusiastic teacher reactions gained by BRL's Programmed Text/Tape Courses in French, German, and Spanish.

Programmed instruction is especially effective in the teaching of languages. Logically structured, designed to maintain student interest and reinforce learning success, BRL Programmed Text/Tape Courses are now recognized by language teachers to offer these unique advantages:
- Designed for individual instruction.

- Flexible - can be used as a basic course, as a well-organized laboratory section, or for individual remedial and review work.

- Increase student understanding and participation.

- Allow more class time for discussion and conversation.

- Assure learning success for higher proportion of students.

Ask about BRL Text/Tape Courses in French, German, and Spanish. Also available are supplementary programs in French: FRENCH READING AND WRITING and FRENCH PHONETICS.

All BRL Programs are available without obligation for evaluation and trial use in your school. Request these BRL Programs on 60 - day approval. If, after you have worked with these materials in your own teaching situation, you don't feel that they are the most interesting and exciting language teaching tools you've seen in a long time, simply return them without further obligation. Mail the coupon today!

\section{BAL BEHAVIORAL RESEARCH LABORATORIES}

\section{(Ladera Professional Center) Box 577, Palo Alto, California 94302}

- Please send me the BRL Language Programs indicated below on 60-day approval.

- Please send me further information on the BRL Language Programs checked below.

_- Please have the local BRL Representative contact me to discuss use of BRL Programs in our language curriculum. My phone no.

BASIC COURSES

French A, 2 Textbooks, 8 Tapes . . \$ 96.22

_ French B, 3 Textbooks, 11 Tapes . . \$132.59

_ German A, 10 Textbooks, 12 Tapes. $\$ 138.71$

- German B, 5 Textbooks, 14 Tapes . \$132.75

_ Introductory Spanish,

7 Textbooks, 7 Tapes .... \$81.50

SUPPLEMENTARY COURSES

French Reading and Writing, 3 Texts . \$17.31

French Phonetics, 1 Textbook, 3 Tapes $\$ 50.00$
Name

School

Address

City

State Zip Code All prices shown are net school prices including Teacher's Manuals and Test Books. 


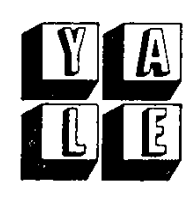

\title{
Patterns of Fallure in La Comédie humaine
}

\section{by Charles Affron}

By demonstrating that the destiny of each of Balzac's heroes is dependent upon his knowledge of and obedience to certain laws and rules, this study offers a coherent view of the universe of La Comédie humaine.

\section{The Imagination of Spring}

The Poetry of Afanasy Fef

by Richard F. Gustafson

The work of perhaps the most "modern" nineteenth-century Russian poet is introduced and analyzed in terms of theme and technique in this first extended study of Afanasy Fet's verse in any Western language.

\section{The Pllgrim's Progress and Traditions in Puritan Meditation}

\section{by U. Milo Kaufmann}

This reexamination of Bunyan's masterpiece argues that the work is much more than religious allegory, that its use of the materials of authoritarian faith bears witness to the intellectual unsettledness of an age much like our own.

\section{The Heart Prepared}

Grace and Conversion in Puritan Spiritual Life by Norman Pettit

The author traces the development of the concept of grace and conversion during the 16 th and 17th centuries, demonstrates its influence on the leading New England divines, describes the debates aroused by it, and explores the problem that arose when preparation became a requirement for church membership, making admission standards too high.

\section{Of Related Interest:}

\section{The Correspondence of Horace Walpole}

Volumes 1-22 and 28-34 now available.

Each volume $\$ 17.50$

\author{
available through your bookstore \\ Yale University Press $\mathbf{Y A}$ \\ New Haven and London $\mathbf{Z}$ \\ in Canada: McGill University Press
}




\section{CHILTON BOOKS}

provide materials, methods, and teacher education for foreign language instruction at all levels. Write for free Catalog and Handbook to:

\section{CENTER FOR CURRICULUM DEVELOPMENT \\ IN AUDIO-VISUAL LANGUAGE-TEACHING}

401 WALNUT STREET

PHILADELPHIA, PA. 19106

\section{LOOKING FOR A BOOK PUBLISHER?}

It is no secret that publication is regarded as the foundation stone of a scholar's career. In order to gain recognition, prestige, and advancement, the scholar must seek publication.

Here at Exposition Press, we offer scholars a complete publishing service, under our special academic imprint, "Exposition-University Books." Though the proportion of scholarly publications in the lists of the trade houses is shrinking, due to economic pressures, many of our recent titles in the academic fields have gained popular reviews, professional recognition and steady sales. These books are the result of a publishing plan that is bringing a steady flow of scholarly writers to Exposition Press. They reflect the high editorial standards and quality of design and production which have won the respect of libraries, schools, booksellers and critics. Ask for free catalogs.

FREE! The behind-the-scenes story of book publishing revealed in two fact-filled, illustrated brochures, containing a detailed description of our subsidy plan including a breakdown of contract terms and typical costs (in print for the first time). Copies are available on request. Your inquiries and manuscripts are invited. An editorial appraisal will be furnished promptly without obligation. References upon request.

\section{Please write to Peter Mason, Editorial Department.}

EXPOSITION PRESS, Main Office, 386 Park Ave. So., Nere York 16, N.Y. California office: 9172 Sunset Blvd., Los Angeles 69, Calif. 


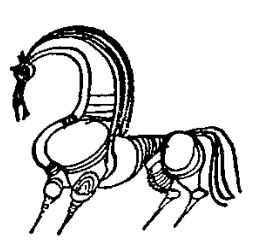

\title{
THE MODERN SHORT STORY IN PERU
}

\author{
by Earl M. Aldrich
}

In the past sixty years the modern short story has become the most cultivated and significant type of fiction in Peru. Working from primary sources, Professor Aldrich examines significant phases in the maturation of this art form, relating poignant biographical data and abundant quotations to the specific works. about 216 pages $\$ 6.00$

\section{SPAIN AND THE WESTERN TRADITION: \\ The Castilian Mind in Literature from EL CID to Calderón, Volume IV

$$
\text { by Otis H. Green }
$$

Otis H. Green's study of Spain's magnificent display of originality and energy in literature during the baroque period within the framework of her declining greatness as a nation is a brilliant climax to his series. Although each volume is an independent entity, Volume IV affords an excellent multiple index to the entire series. about 360 pages $\$ 7.50$

\section{THE GEATS OF BEOWULF:}

\section{A Study in the Geographical Mythology of the Middle Ages by Jane Acomb Leake}

Despite generations of intense critical scrutiny, the identity of Beowulf's people remains unresolved. Examining the problem from the viewpoint of the historical geographer, Mrs. Leake advances the new and startling thesis that the Geats may have been the Getae, a tribe of ancient Thrace. about 320 pages, 4 illus. $\$ 7.50$

\section{LITERARY MONOGRAPHS, VOLUME I \\ edited by Eric Rothstein and Thomas K. Dunseath}

This volume inaugurates a series of publications sponsored by the English Department of the University of Wisconsin and designed to offer a nonparochial and eclectic outlet for papers of intermediate length in English and American literature. about 320 pages, 4 illus. $\$ 7.50$

\section{W WISCONSIN PRESS \\ BOX 1379 \\ MADISON, WISCONSIN 53701}




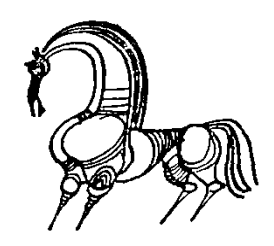

\title{
KANNADA: A CULTURAL INTRODUCTION TO THE SPOKEN STYLES OF THE LANGUAGE
}

\author{
by William McCormack, with the \\ assistance of M. G. Krishnamurthi
}

This course of twenty graded units in spoken and literary Kannada provides a detailed introduction to the language and culture of some twenty million inhabitants of Mysore State, in South India. about 216 pages $\$ 5.00$

\section{THE SCALE OF PERFECTION \\ and the English Mystical Tradition \\ by Joseph E. Milosh}

In this first comprehensive study of Walter Hilton's major work, Joseph E. Milosh approaches The Scale of Perfection as one of the most important mediaeval contemplative works as well as a good measure for judging other literature in the mystical tradition. about 224 pages $\$ 6.50$

\section{MELVILLE'S READING: \\ A Check-List of Books Owned and Borrowed \\ by Merton M. Sealts, Jr.}

The initial version of Melville's Reading appeared serially in the Harvard Library Bulletin between 1948 and 1950. Now first published in book form, it has been thoroughly revised and expanded to reflect new information concerning Melville and his library. about 144 pages, 11 illus. $\$ 6.00$

\section{THE TRANSLITERATION OF MODERN RUSSIAN FOR ENGLISH-LANGUAGE PUBLICATIONS}

\section{by J. Thomas Shaw}

To meet the needs of a variety of publications, this booklet presents four systems for translating modern Russian Cyrillic. Not only does Professor Shaw give detailed advice on the use of appropriate systems for particular audiences, but he also provides practical answers to various special transliteration problems. about 16 pages $\$ 1.00 @$; package of five $\$ 3.00$; ten or more copies $\$ 0.50 @$

At your bookseller or write direct.

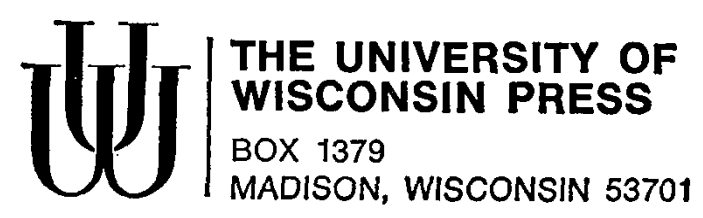




\section{Stankevich and His Moscow Circle, 1830-1840}

Edward J. Brown. Stankevich, whose influence endured far beyond his death at 27 , was the leader of a group at Moscow University that included Turgenev, Bakunin, Herzen, Belinsky, and Granovsky. This biographical study-the first in a Western language-is an unusually compelling evocation of the intellectual and emotional atmosphere of Russia in the exciting time when Russian literature was taking its first steps toward greatness.

\section{Twenty Years of Stanford Short Stories}

Edited by Wallace Stegner and Richard Scowcroft. A selection of the finest stories to emerge from the first twenty years of the Creative Writing Center at Stanford University, many of whose students have gone on to successful careers as writers.

Cloth, $\$ 6.95$; paper, $\$ 2.95$

\section{Sherwood Anderson}

Irving Howe. A REISSUE. "The first full critical biography to deal with Anderson and his work .... it is the record of a deeply personal relation to Anderson's work, not merely intellectual mastery of it. . . . Howe writes about Anderson's work with a quiet, patient, discerning, instructed power that makes his own book itself a literary event."-The New York Times Book Review Cloth, \$6.00; paper, \$2.95

\section{NOW AVAILABLE IN PAPERBACK \\ Byron}

A Critical Study. Andrew Rutherford. "An excellent study, comprehensive and unified, with an admirable soundness of judgment."-Studies in English Literature. "The best single study of Byron as poet so far produced."-Books Abroad $\$ 2.95$

\section{The Wake of the Gods: Melville's Mythology}

H. Bruce Franklin. "An absorbing study ... Even the most startling of Franklin's identifications . . . are brilliantly supported by evidence."-The Modern Language Review. "Unusually interesting and readable."-Modern Fiction Studies

\section{Some Shakespearean Themes \& An Approach to "Hamlet"}

L. C. Knights. Two volumes in one. [The importance of Knight's books] lies ... in the rare and stimulating experience they offer of contact with a mind that is ... deeply responsive to the beauty and meaning of Shakespeare's plays."-Modern Philology

\section{"Leaves of Grass"' One Hundred Years After}

Edited by Milton Hindus. Essays by William Carlos Williams, Richard Chase, Leslie Fiedler, Kenneth Burke, David Daiches, J. Middleton Murry. "Certain to inspire many readers to go back and read Whitman himself."--The New Leader 


\title{
Published by M LA
}

Distributed by New York University Press

\section{The English Romantic Poets and Essayists}

\author{
A Review of Research and Criticism \\ Revised Edition
}

Carolyn Washburn Houtchens and Lawrence Huston Houtchens, Editors

Revised to include research up to 1964, this edition of an indispensable scholarly aid covers the research and criticism on eleven Romantic authors: William Blake, Charles Lamb, William Hazlitt, Sir Walter Scott, Robert Southey, Thomas Campbell, Thomas Moore, Walter Savage Landor, Leigh Hunt, Thomas De Quincey, and Thomas Carlyle.

464 pages $\$ 6.50$

\section{The Medieval Literature of Western Europe}

\author{
A Review of Research, Mainly 1930-1960 \\ John H. Fisher, Editor
}

Here is a volume, remarkable in its coverage and distinguished in its judgments, that offers a guide through the wealth of scholarship in eleven major western European medieval literatures: Latin, Old English, Middle English, French, German, Old Norse, Italian, Spanish, Catalan, Portuguese, and Celtic. 408 pages $\$ 6.50$

ORDER FROM

New York University Press $\cdot 32$ Washington Place $\cdot$ New York City 10003 (Distributed in England by the University of London Press) 


\section{American $\mathcal{U}_{\text {niversity }} \mathcal{P}_{\text {resses }}-\mathcal{F}_{\text {orthcoming }} \mathcal{P}_{\text {ublications }}$}

\section{AMERICAN LITERATURE AND LANGUAGE}

The Family Letrers of Thomas Jefferson, ed. by Edwin Morris Betts and James Adam Bear, Jr., Missouri, November, $\$ 10.00$

SOUTHERN WRITING IN THE SIXTIEs: Fiction, ed. by John William Corrington and Miller Williams, Louisiana State, September, $\$ 2.95$ paperbound; $\$ 7.50$ clothbound

Conceptions of Rentirty in Modern American Poetry, by L. S. Dembo, California, September, $\$ 6.00$

ENGLish TRAITs, by Ralph Waldo Emerson, ed. by Howard Mumford Jones, The John Harvard Library of the Belknap Press of Harvard University Press, November, $\$ 5.00$

The Added Dimension: The Art and Mind of FlanNERY O'CONNOR, ed. by Melvin J. Friedman and Lewis A. Lawson, Fordham, September, $\$ 6.00$

TOUgH, SWEet AND STUfFy: AN EsSAy ON MODERN AMERICAN Prosb StYles, by Walker Gibson, Indiana, November, $\$ 4.50$

Beyond Defeat: AN Epllogur to AN ERA, by Ellen Glasgow, intro. by Luther Yates Gore, Virginia, October, $\$ 5.00$ tentative

Stories From "Epoch": ThB First Fifty Issues, 1947. 1964 , ed. by Baxter Hathaway, Cornell, November, $\$ 7.50$

The Lovingood Papers 1965, ed. by Ben Harris McClary, Tennessee, September, $\$ 2.00$

Writers on FAULKNER: AN ANTHOLOGY, by James B. Meriwether, Tex2s, September, $\$ 5.00$

Thr Journals and Miscellaneous Notebooks of RALPH WaLDO EMERSON, Vol. VI, 1824-1838, ed. by Ralph H. Orth, The Belknap Press of Harvard University Press, November, $\$ 12.00$

HENRY JAMES: Representattve SElectrons, with Introduction, Bibliography, and Notes by Lyon N. Richard son, Illinois, September, $\$ 3.50$ paperbound

Melville's Reading: A Check-List of Books Owned AND BORROWED, by Merton M. Sealts, Jr., Wisconsin, October, $\$ 6.00$

WORLD WITHIN WORID: THE AUTOBIOGRAPHY OF STE. PHEN SPENDER, California, September, $\$ 1.75$ paperbound

Theodorb RoethKe: Essays on the POETRY, ed. by Arnoid Stein, Washington, September, $\$ 2.95$ paperbound

Dear Ones at Home: LetTers of LUCy aNd SARAH CHase (19th Century original letters), by Henry $I$. Swint, Vanderbilt, September, $\$ 6.95$

JACK LONDON AND THB KLONDIKE: THB GENESIS OF AN AMERICAN WRITER, by Franklin Walker, Huntington Library, September, $\$ 5.00$

ThE ACHIEVEMENT OF SHERWOOd ANDERSON: ESSAYS IN Criticism, by Ray Lewis White, North Carolina, September, $\$ 7.50$

\section{BIBLIOGRAPHY}

Law Books in Spanish Transiation, by Phanor J. Eder, Florida, October, $\$ 15.00$

American Fiction 1876-1900: A Contribution Toward A Bibliography, by Lyle $\mathrm{H}$. Wright, Huntington Library, September, $\$ 15.00$

\section{COMPARATIVE LITERATURE}

ARChetypes of THE FamiLy IN Literaturb, by Sven Armens, Washington, October, $\$ 6.95$

The Troublesome Helpmate: A History of Misogyny IN LITRRATURE, by Katharine Munzer Rogers, Washington, October, \$6.95
Honey and Wax: Pleasures and Powers of NarraTrVE, An Anthology assembled by Richard Stern, Chicago, September, $\$ 7.95$

\section{DRAMA}

The OresteiA, by Aeschylus, adapted by John Lewin, Minnesota Drama Editions No. 2, ed. by Sir Tyrone Guthrie, Minnesota, November, $\$ 1.25$ paperbound, $\$ 5.00$ clothbound

What is Cinema? by André Bazin, Essays selected and translated by Hugh Gray, California, November, $\$ 4.50$

The Theatre of the French Revolution, by Marvin Carlson, Cornell, September, $\$ 8.50$

The Complete Plays of Wilitiam Congreve, Curtain Playwright Editions series, ed. by Herbert Davis, Chicago, November, $\$ 12.50$

The Memoir of John Durang: American AC'tor: 1785 1816 , ed. by Alan S. Downer, Pittsburgh, October, $\$ 7.00$

ItALIAN PlaYS, 1500-1700, IN THE UNIVERSITY OF ILLINOIS LIBRARY, compiled by Marvin T. Herrick, Illinois, September, $\$ 5.75$

"MOdERNISM" in MODERN DRAMA: A Definition AND aN Estimate, by Joseph Wood Krutch, Cornell, November, $\$ 1.45$ paperbound

Shakespeare SuRVey 19, Macbeth, ed. by Kenneth Muir, Cambridge, October, $\$ 8.50$

Tragedy and THE Theory of Drama, by Elder Olson, Wayne State, November, $\$ 2.95$ paperbound, $\$ 6.95$ clothbound

Shakespeare's Romantic Comedies: The Development of Their Forms and Meaning, by Peter G. Phialas, North Carolina, November, \$7.50

Hugo von Hofmannsthal: THRE Plays, trans. with an intro. by Alfred Schwarz, Wayne State, November, $\$ 2.95$ paperbound; $\$ 5.50$ clothbound

Traditional Chinese Plays: Ssu lang Visits His Mother, and THe ButTerfly Dream, by A. C. Scott, Wisconsin, November, $\$ 6.50$

Gilbert Before Sullivan: Six Comic Plays, ed. by Jane W. Stedman, Chicago, November

Major Historical Plays of Strindberg: The Vasa TRILOGY, trans. and intro. by Walter Johnson, Washington, September, $\$ 2.95$ paperbound

Five Evenings, by Aleksandr Volodin, trans. and adapted by Ariadne Nicolaeff, Minnesota Drama Editions No. 3, ed. by Sir Tyrone Guthrie, Minnesota, November, $\$ 1.00$ paperbound; $\$ 4.50$ clothbound

\section{ENGLISH LANGUAGE AND LITERATURE}

Circle of Fire: Dickens' Theatrical Vision and Styin AND THE POPUlaR Victorian Theatre, by William $F$. Axton, Kentucky, $\$ 7.50$

The Familiar LetTer IN the Eightenenth Century, ed. by Howard Anderson, et al., Kansas, September, $\$ 7.00$

ON EDITINg Shakespeare, by Fredson Bowers, Virginia, September, $\$ 2.25$ paperbound, $\$ 4.00$ clothbound tentative

The Letters of Mrs. Gaskell, ed. by J. A. V. Chapple and A. Pollard, Harvard, September, $\$ 22.50$ two vol set

a HaNd-Book for Travellers in SPAIN and Readers AT Home, by Richard Ford, Southern Illinois, September, $\$ 50.00$

Heaven Beguiles the Tired: Drath in xhe Poetry of Emily Dickinson, by Thomas W. Ford, Alabama, September, $\$ 4.95$

SBlected Prose of John Hamilton Reynolds, ed. by Leonidas M. Jones, Harvard, September, $\$ 12.50$ 


\section{American $\mathcal{U}_{\text {niversity }} \mathcal{P}_{\text {resses }}-\mathcal{F}_{\text {orthcoming }} \mathcal{P}_{\text {ublications }}$}

Patterns of Love and Courtesy: Essays in Memory of C. S. LEwis, ed. by John Lawlor, Northwestern, October, $\$ 4.95$

Pope's Horatian Poems, by Thomas E. Maresca, Ohio State, November, $\$ 5.00$

THE ILL-FrAMED KNIGHT: A SKEPTICAL INQUIRY INTO THE IDENTITY OF SIR THOMAS MALORY, by William Matthews, California, September, $\$ 6.95$

WORDSWORTH: THE CHRONOLOGY OF THE EARIY YeARS, 1770-1799, by Mark L. Reed, Harvard, November, $\$ 9.00$

a Critical Anthology of English Recusant DevoTIONAL Prose, 1558-1603, by John R. Roberts, Duquesne, September, $\$ 8.00$ tentative

GodWIN and Mary: THe LetTers of Wir.liam Godwin AND MARY WOLlSTONECRAFT, ed. by Ralph M. Wardle, Kansas, September, $\$ 4.00$

The Disciplined Heart: Iris Murdoch and Her NovELs, by Peter Wolfe, Missouri, October, $\$ 5.95$

HeNRY FIELDING: MASK AND FEAST, by Andrew Wright, California, September, $\$ 1.50$ paperbound

\section{FOLKLORE}

I Could Talk Old Story Good: Creatrutty in BaHAMIAN FolKLORE, by Daniel J. Crowley, California, September, $\$ 6.00$ paperbound

Painted Walls of Mexico: From Prehistoric Times UNTIL TODAY, text by Emily Edwards, photographs by Manuel Alvarez Bravo, Texas, October, $\$ 12.50$

The Ritual TheORY OF MYTH, by Joseph E. Fontenrose, California, September, $\$ 4.00$ paperbound

THE MIDWIFE AND THE WITCH, by Thomas R. Forbes, Yale, October, $\$ 6.50$

The Tsimshian Indians and Their ARts, by Viola E. Garfield and Paul S. Wingert, Washington, September, $\$ 2.95$ paperbound

Fables of the Jewish Aesop Translated from the FoX Fables OF BERECHIAH Ha-NAKDAN, trans, by Moses Hadas, Columbia, October, $\$ 5.00$

THE Rock ART of TEXas Indians, text by W. W. Newcomb, Jr., paintings by Forrest Kirkland, Texas, November, $\$ 12.50$

Eskimo MASKS: ART AND CeremonY, by Dorothy Jean Ray, Washington, November, $\$ 12.50$

FolkTALEs of GermaNY, ed. by Kurt Ranke, trans. by Lotte Baumann, Chicago, September, $\$ 5.50$

FolkTAles OF IRELAND, ed, and trans, by Sean O'Sullivan, Chicago, September, $\$ 5.50$

HORSEMBN OF THB AMERICAS AND THB LITERATURB They INSPIRED, by Edward Larocque Tinker, Texas, November, $\$ 10.00$

\section{FRENCH LANGUAGE AND LITERATURE}

The Strangers-The Tragic World of Tristan L'Hermite, by Claude K. Abraham, Florida, October, $\$ 2.00$

Tha EpIC Quest: Studies IN Four Old Chansons De Geste, by William Calin, Johns Hopkins, September, $\$ 7.50$

ROUSSEAU'S VENETIAN STORY: AN ESSAY UPON ART AND TRUTH in Les Confessions, by Madeline B. Ellis, Johns Hopkins, September, $\$ 6.00$

JeAN Cocteau: The History of A POET's AgB, by Wallace Fowlie, Indiana, October, $\$ 5.00$

Trends and Styles in 20th Century French LiteraTURB, by Helmut A. Hatzfeld, Catholic, September, $\$ 10.00$
Some French Canadian Thinkers of the Nineteenth AND Twentieth Centures, ed. by Laurier LaPierre, McGill, October, $\$ 2.75$

Ies Oeuvres de PIerre de Ronsard: TeXt of 1587, Vols. I and II [in French], ed. by Isidore Silver, Chicago, November, $\$ 15.00$

\section{HISTORY OF IDEAS}

Aristotle's Metaphysics, by Hippocrates G. Apostle, Indiana, November, $\$ 12.50$

The History of Philosophy: The Seventeenth CenTURY, by Ëmile Bréhier, trans. by Wade Baskin, Chicago, November, $\$ 8.50$

The Political Ideas of the English Romanticists, by Crane Brinton, Michigan, September, $\$ 1.95$ paperbound

The Triumph of TIMe: A Study of the Victorian Concepts of Time, History, PROgRess, and DecaDENCE, by Jerome H. Buckley, The Belknap Press of Harvard University Press, September, $\$ 4.50$

Greek Orations: Lysias, Isocrates, Demosthenes, AEsChines, HyPERIDES, ed. by W. Robert Connor, Michigan, August, $\$ 5.95$ clothbound; September, $\$ 2.25$ paperbound

Christian Ethics, by Isma'il Ragi Al Faruqi, McGill, October, $\$ 13.50$

AEsthetIC THEORIES OF FRENCH ARTISTS: From REALISM to Surrealism, by Charles Edward Gauss, Johns Hopkins, October, $\$ 1.45$ paperbound; $\$ 3.50$ clothbound

SELECTED WRITINGS, by Remy de Gourmont, trans. and ed. with an intro. by Glenn S. Burne, Michigan, October, $\$ 5.95$

California's Utopian Colonies, by Robert V. Hine, Yale, September, $\$ 1.43$ paperbound; $\$ 6.00$ clothbound

Ethico-Religious Concepts in THB QUR'AN, by Toshihiko Izutsu, McGill, October, $\$ 9.00$

StUdies in Christian Existentlalism, by John Macquarrie, McGill, October, $\$ 6.00$

Philosophy, Science, and Sense Perception: HistoriCAL ANd CRITICAL STUdies, by Maurice Mandelbaum, Johns Hopkins, October, $\$ 2.45$ paperbound; $\$ 6.50$ clothbound

Teaching to Read: Historically Considered, by Mitford M. Mathews, Chicago, October, $\$ 6.95$

SURREAlism AND THE NOvel, by J. H. Matthews, Michigan, September, $\$ 5.95$

PATRons and PATRIOTISM: THE ENCOURAgement OF THB Fine ARts IN THe UNITED States $1790-1860$, by Lillian B. Miller, Chicago, September, $\$ 8.50$

Believing AND KNowING, by Emerson W. Shideler, Iowa State, October, \$4.95 tentative

Transcendentalism and its Legacy, ed. by Myron Simon and Thornton H. Parsons, Michigan, November, $\$ 6.93$

KANT: PHILOSOPHICAL CORRESPONDENCE 1759-1799, ed. and trans. by Arnulf Zweig, Chicago, November

\section{ITALIAN LANGUAGE AND LITERATURE}

A Guide to Composition in Italian, by Toni Cerutti, Cambridge, September, $\$ 1.00$

Leopardi: Poems AND Prose, ed. by Angel Flores, Indiana, November, $\$ 2.95$ paperbound; $\$ 6.75$ clothbound

\section{LEXICOGRAPHY}

Americanisms: A Dictionary of Selected Americanisms ON Historical Principles, by Mitford M. Mathews, Chicago, September, $\$ 1.95$ paperbound; $\$ 5.95$ clothbound 


\section{American $\mathcal{U}_{\text {niversity }} \mathcal{P}_{\text {resses }}-\mathcal{F}_{\text {orthcoming }} \mathcal{P}_{\text {ublications }}$}

INDEX TO THE WORkS OF G. K. Chesterton, by Joseph W. Sprug, Catholic, October, $\$ 6.95$

\section{IINGUISTICS}

T. A. INFormations, Alabama, $\$ 2.50$ per issue; $\$ 4.00$ per annual subscription

KHoTANESE TeXTs, 1-3; revised 1-volume edition, by Sir Harold Bailey, Cambridge, October, $\$ 30.00$

Dictionary OF JAMAiCAN ENGiISH, by F. G. Cassidy and R. B. LePage, Cambridge, October, $\$ 22.50$

ON Human COMmunication: A Review, a SuRvey, and A Criticism, 2nd ed., by Colin Cherry, M.I.T., September, $\$ 10.00$

INTRODUCTION $\lambda$ L'ÉTUde DES LANGUAGes DOCUMENTAlREs, by Maurice Coyaud, Alabama, September, $\$ 6.95$

A Concise Grammar of the Sanskrit Language, by Jan Gonda, Alabama, October, \$5.95

German Grammar III, by Peter Jorgensen, New York, September, $\$ 6.00$

The Categories and Types of Present-Day English WORD ForMation, by Hans Marchand, Alabama, October, $\$ 7.50$

Linguistics AND the Teaching of ENglish, by Albert H. Marckwardt, Indiana, November, $\$ 4.75$

Elements of General Linguistics, by André Martinet, Chicago, September, $\$ 1.95$ paperbound; $\$ 6.50$ clothbound

The Genesis of Language: A Psycholinguistic ApPronCH, by Frank Smith and George Miller, M.I.T., September, $\$ 10.00$

\section{LITERARY CRITICISM}

The MOdern ShORT StORY IN PERU, by Earl M. Aldrich, Jr., Wisconsin, September, $\$ 6.00$

FaUlkNer: The Major Years: A Critical Study, by Melvin Backman, Indiana, September, $\$ 1.95$ paperbound; $\$ 5.75$ clothbound

Gerard Manley Hopkins: The Classical Background and Crutical Reception of His Work, by Todd $K$. Bender, Johns Hopkins, November, $\$ 5.95$

JOYCE-AgAIN'S WAKE: AN ANALYSIS OF FINNEgAN'S WAKE, by Bernard Benstock, Washington, September, $\$ 2.95$ paperbound

Sir Gawain and Peari: Critical Essays, ed. by Robett J. Blanch, Indiana, November, $\$ 2.95$ paperbound; $\$ 6.75$ clothbound

LANGUAGB AS SYMBOLIC ACTION: ESSAYS ON LIFE, LITERATURE, AND METHOD, by Kenneth Burke, California, November, $\$ 6.95$

The Recognition of Edgar Allan Pob, ed. by Eric W. Carlson, Michigan, November, $\$ 7.50$

The Dramatic Craftsmanship of Moreto, by Frank $P$. Casa, Harvard, September, $\$ 5.00$

TENNESSEz StUdies IN LITERATURr, Vol. XI, ed. by Richard Beale Davis and Kenneth L. Knickerbocker, Tennessee, September, $\$ 2.00$

Marx, Engels, and tHe Ponts: Origins of Marxist LITERARY CRITICISM, by Peter Demetz, trans. by Jeffrey L. Sammons, Chicago, November

Jean Genet, by Tom Driver, Columbia, $\$ .65$

"The Pilgrim's Progress" and Traditions in Puritan Meditation, by V. Milo Kaufman, Yale, October, $\$ 6.50$

The Dickens Critics, ed by George H. Ford and Lauriat Lane, Jr., Cornell, November, $\$ 2.45$ paperbound

STYLE AND TEMPER: STUdies IN FRENCH FiCTION, 19251960 , by Wilbur M. Frohock, Harvard, October, \$3.95
Images of the Negro IN American Literature: EsSaYs in Criticism, ed. by Seymour L. Gross and John Edward Hardy, Chicago, October, $\$ 2.95$ paperbound, $\$ 6.50$ clothbound

JoHN DONNE, PETRAR CHIST: ITALIANATE CONCEITS AND LOVE THEORY IN THE SONGS AND SONETS, by Donald L. Guss, Wayne State, October, $\$ 8.95$

MaN IN The MOderin Novel, by John Edward Hardy, Washington, September, $\$ 2.45$ paperbound

Tragedy, MYTH AND MYSTERY, by Richmond Y. Hathorn, Indiana, November, $\$ 2.65$ paperbound; $\$ 6.75$ clothbound

The Soothsayings of Bakis: Goethe's Tragi-Comic Observations ON Life, TIMe, AND History, by Harold Jantz, Johns Hopkins, November, $\$ 4.95$

The Passive Voice: AN Appronch to Modern Fiction, by Harold Kaplan, Ohio, September, $\$ 5.00$

British Romantic Poets: Recent Revaluations, ed. by Shiv K. Kumar, New York, October, $\$ 2.75$ paperbound; $\$ 7.50$ clothbound

F. SCOTt Fitzgerald and the Craft of Fiction, by Richard D. Lehan, Southern Illinois, October, $\$ 4.95$

From West to East: Studies in the Literature of the American WEST, by Robert Edson Lee, Illinois, October, $\$ 5.00$

Gerard Manley Hopkins, by Francis Noel Lees, Columbia, $\$ .65$

The Hero with the Private Parts: Essays, by Andrew Lytle, Louisiana State, September, $\$ 6.00$

Miguel de Unamuno, by Julian Marias, trans. by Frances M. Lopez-Morillas, Harvard, November, $\$ 4.75$

The Scale of Perfection and the English Mystical Trabition, by Joseph E. Milosh, Wisconsin, October, $\$ 6.50$

JOHN WeBSTRR AND His CRITICS, 1617-1964, by Don D. Moore, Louisiana State, September, $\$ 4.00$

Twentieth.Century French Literature Since WORLd WaR II, by Harry T. Moore, Southern Illinois, October, $\$ 4.95$

Twentieth-Century French Literature to World War II, by Harry T. Moore, Southern Illinois, October, $\$ 4.95$

Say That We Saw Spain Die: Lrterary Consequences OF THE SPANish Civil War, by John M. Muste, Washington, October, $\$ 6.00$

The Poetic Worid of William Carlos Williams, by Alan Ostrom, Southern Illinois, October, $\$ 4.95$

Thr Story of THe Iliad, by E. T. Owen, Michigan, September, $\$ 1.95$ paperbound

Henry James: A Reader's Gumb, by S. Gorley Pütt, Cornell, September, $\$ 6.95$

ExploRATIONS OF Literature, ed. by Rima Drell Reck, Louisiana State, October, $\$ 3.50$

JoSEPH CONRAD AND THE Fiction OP AUTOBIOGRAPHY, by Edward W. Said, Harvard, October, $\$ 4.95$

THE Sociology of Literary TASTE, by Levin L. Schücking, trans. by Brian Battershaw, Chicago, September, $\$ 3.00$

Franz KafkA, by Walter H. Sokel, Columbia, $\$ .65$

EMERSON'S IMPACT ON THE BRITISH ISLES AND CANADA, by William J. Sowder, Virginia, November, $\$ 6.75$ tentative

JAMES JOYCE TODAy: EsSAys ON THE MAjor Works, ed. by Thomas F. Staley, Indiana, November, $\$ 6.00$

THE ACHIEVEMENT OF Shakespeare's "MEASURE FOR Measure," by David Lloyd Stevenson, Cornell, November, $\$ 5.75$ 


\section{American $\mathcal{U}_{\text {niversity }} \mathcal{P}_{\text {resses }}-\mathcal{F}_{\text {orthcoming }} \mathcal{P}_{\text {ublications }}$}

Wallace Stevens: Art of Uncertainty, by Herbert J. Stern, Michigan, November, $\$ 5.95$

Iiterature AND THe Christian Life, by Sallie McFague TeSelle, Yale, November, $\$ 6.50$

T. S. Eliot: MOMENTS AND PATterns, by Leonard Unger, Minnesota, November, $\$ 5.75$

THE LIMITS OF SYMBOLISM: STUDIES OF FIVE MODERN FrenCH POETs, by Bernard Weinberg, Chicago, November

The Senecan Amble: A Study in Prose Form from BACON TO COLLIER, by George Williamson, Chicago, October, $\$ 2.45$ paperbound; $\$ 7.50$ clothbound

HermanN Hesse, by Theodore Ziolkowski, Columbia, $\$ .65$

\section{MEDIEVAL HISTORY AND LITERATURE}

Letters from Petrarch, trans. by Morris Bishop, Indiana, November, $\$ 9.50$

WIMbledon's Sermon: "Redde Rationem Villicatronis TUe," by Ione Kemp Kaight, Duquesne, November, $\$ 8.00$

Thought AND LeTters IN Western Europe, A.D. 500 to 900 , by M. L. W. Laistner, Cornell, November, $\$ 2.45$ paperbound

LAMENTS for the Dead in Medieval Narrative, by Velma Bourgeois Richmond, Duquesne, October, $\$ 8.00$

Charles Il's Escape FROM Worcester, ed. by William Matthews, California, November, $\$ 7.00$

The Transformation of the Roman World: Gibbon's Problem after Two Centurues, ed. by Lyan White, Jr., California, October, $\$ 6.00$

\section{POETRY}

The Poetry of Theodore Roethre: A Critical Study, by Karl Malkoff, Columbia, September, $\$ 7.50$

Northfield Poems, by A. R. Ammons, Cornell, October, $\$ 3.95$

Nikal Seyn and Decoration Day: a Poem and A Play, by Louis Coxe, Vanderbilt, November, $\$ 4.00$

The Day I Stopped Dreaming about Barbara Steele And Other Poems, by R. H. W. Dillard, North Carolina, November, $\$ 1.85$ paperbound, $\$ 3.75$ clothbound

Poems from KenYa: GNomic Verses in Swahili, by Ahmad Nassir bin Juma Bhalo, trans. and ed. by Lyndon Harries, Wisconsin, November, $\$ 5.00$

Porms AND Frngments, a Bilingual Edition, by Friedrich Holderlin, trans. by Michael Hamburger, Michigan, November, $\$ 10.00$

AN Upland Pasture, by Theodore Holmes, Vanderbilt, November, $\$ 4.00$

The Animal Inside: Poems, by Josephine Jacobsen, Ohio, September, $\$ 4.00$

Rrvers Into Is lands, by John Knoepfle, Chicago, October, $\$ 1.50$ paperbound; $\$ 3.50$ clothbound

Modern Hzbrew Poetry: A Bllingual ANthology, trans. and ed. by Ruth Finer Mintz, California, October, $\$ 7.00$

The Verse of Royall Tyler, by Marius B. Péladeau, Virginia, September, $\$ 6.75$ tentative

Strll Lives and Other Lrves, by Saul Touster, Missouri, November, $\$ 3.50$

AMyntas 1585, by Thomas Watson with The LAMENTATIONS OF AMINTAS 1587, trans. by Abraham Fraunce, Chicago, November
Domains: Poems, by James Whitehead, Louisiana State, November, $\$ 3.50$

Thr Cutring Edge, by John Woods, Indiana, November, $\$ 3.75$

Something of Great Constancy: The Art of "A Midsummer Night's Dream," by David P. Young, Yale, November, $\$ 5.00$

\section{PORTUGUESE LANGUAGE AND LITERATURE}

The Modernist Movement in Brazil, by John Nist, Texas, November, $\$ 5.00$

\section{SCANDINAVIAN LANGUAGE AND LITERATURE}

Two Minutes of SilenCe, by H. C. Branner, trans, from the Danish by Vera Lindholm Vance, Wisconsin, November, $\$ 5.00$

Modern Norwegian literature, by B. W. Downs, Cambridge, October, $\$ 9.50$

My CHILdhood, by Toivo Pekkanen, trans. from the Finnish by Alan Blair, Wisconsin, November, $\$ 5.00$

Jorgen STEIN, by Jacob Paludan, trans. from the Danish by Carl Malmberg, Wisconsin, November, $\$ 7.95$

\section{SLAVIC AND EAST EUROPEAN LANGUAGE AND LITERATURE}

The Notebooks for "Crimb and Punishment," by Fyodor Dostoevsky, ed. and trans. by Edward Wasiolek, Chicago, November

Marina Cvetaeva: Her Life and ARt, by Simon Karlinsky, California, September, $\$ 7.25$

A Concise History of Russian Literature: Vol. 1: FROM THE BEgINNINGS TO CHEKHOV, by Thais Lindstrom, New York, October, $\$ 2.25$ paperbound; $\$ 6.00$ clothbound

RUssian Normattvi Stress Notation, by John Greer Nicholson, McGill, October, $\$ 9.00$

Begnnning Polish, Vol. I, by Alexander M. Schenker, Yale, October, $\$ 3.75$ paperbound; $\$ 7.50$ clothbound

\section{SPANISH LANGUAGE AND LITERATURE}

Spain and the Western Tradition: The Castilian Mind in literature from El Cid to Calderón, Vol. IV, by Otis H. Green, Wisconsin, October, $\$ 7.50$

Selected Poems of Rafael Alberti, trans. by Ben Belitt, California, September, $\$ 1.75$ paperbound

The Other Side of the Mirror: El Grimorio, by Enrique Anderson Imbert, Southern Illinois, November, $\$ 5.95$

Reality and the Poet in Spanish Poetry, by Pedro Salinas, Johns Hopkins, October, $\$ 1.95$

LA Celestina or the SPANish BAwD, by Fernando de Rojas, trans. by J. M. Cohen, New York, November, $\$ 5.00$

\section{SPEECH AND PHONETICS}

Op Eloquence: Studies in Ancient and Mediaeval RHeroR!C, by Harry Caplan, ed. by Anne King and Helen North, Cornell, November, $\$ 7.00$

The Disabled Reader: Education of the Dyslexic CHILD, ed. by John Money and Gilbert Schiffman, Johas Hopkins, September, $\$ 8.50$ 


\section{Announcing... the first \\ three volumes of an important Anthology from Washington Square Press}
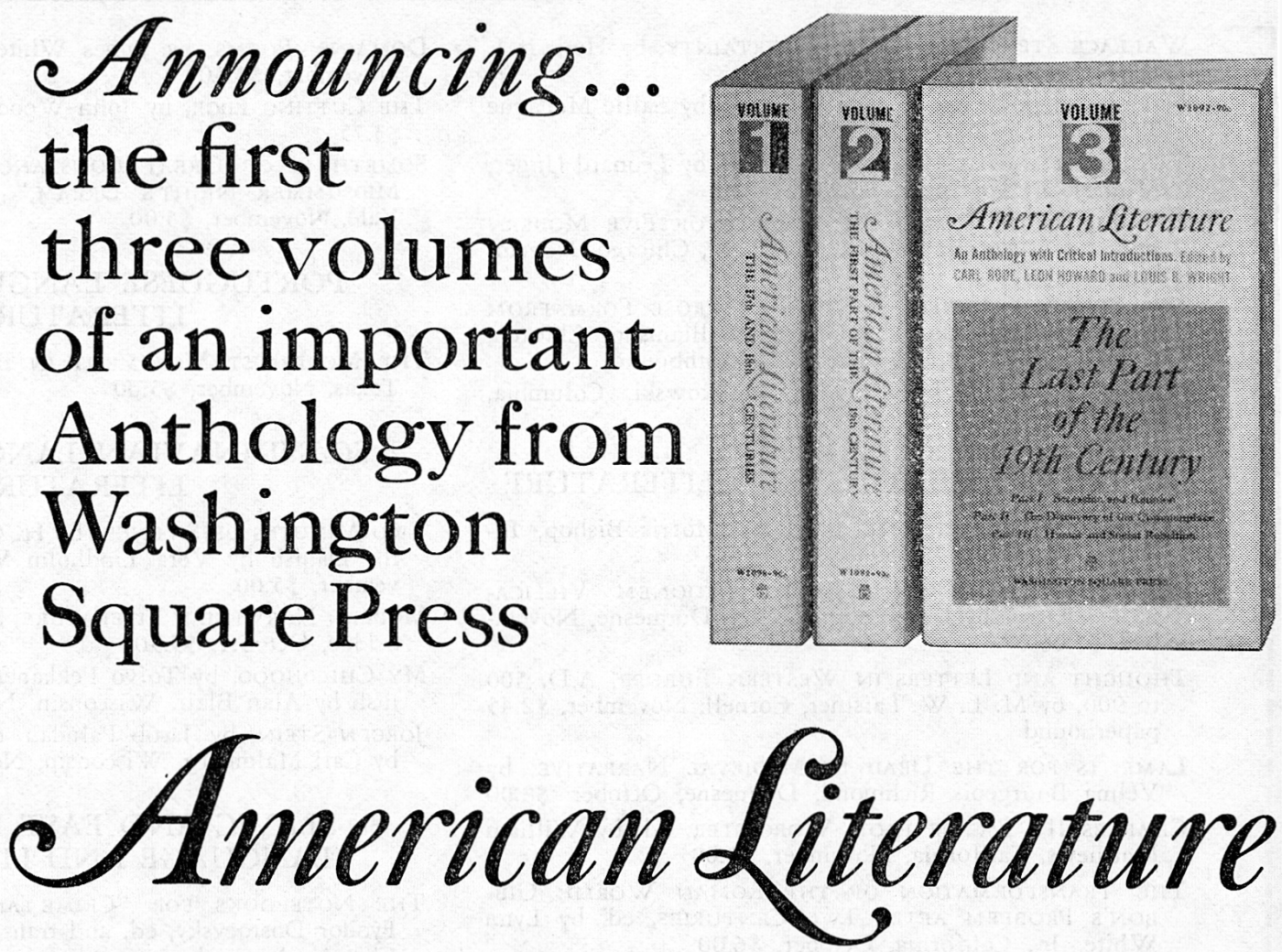

This distinguished series of critical anthologies contains introductions by Carl Bode, University of Maryland; Leon Howard, University of California at Los Angeles; Louis B. Wright, Director, Folger Shakespeare Library.
Each volume includes the complete texts and representative selections of the most important works of the period; critical introductory essays preceding each section; biographical information and annotated bibliographies for each author.

\section{Vol. 1-The 17th and 18th Centuries}

Vol. 2-The First Part of the 19th Century

Vol. 3-The Last Part of the 19th Century

Each volume only $90 \phi$.

The special INTRODUCTORY OFFER on the facing page includes the new anthology of American Literature as well as a selection of individual classics of American literature published by Washington Square Press. All are unabridged, most with critical introductions and notes by eminent scholars.

MSP All "WSP" books are edited with great care... and are modestly priced. 
Introductory Offer: any three volumes for $\$ 1.00$

AMERICAN LITERATURE

$\square$ VOL. 1, THE 17th \& 18th CENTURIES W1090 90\%

VOL. 2, FIRST PART OF 19th CENTURY W1091 906

$\square$ VOL. 3, LAST PART OF 19th CENTURY W1092 906

BENJAMIN FRANKLIN

THE AUTOBIOGRAPHY OF

BENJAMIN FRANKLIN

W $218 \quad 45 \dot{c}$

WASHINGTON IRVING

$\square$ THE LEGEND OF SLEEPY HOLLOW

AND OTHER SELECTIONS

W $58160 €$

\section{JAMES FENIMORE COOPER}

THE PIONEERS

THE PRAIRIE

W $578 \quad 60 c$

W $57960 c$

EDGAR ALLAN POE

GREAT TALES AND POEMS OF

EDGAR ALLAN POE

W $246 \quad 45 c$

21 tales; 34 poems

\section{NATHANIEL HAWTHORNE}

THE MARBLE FAUN

W $259 \quad 45 \bar{c}$

THE SCARLET LETTER

W $226 \quad 45$ c

TWICE-TOLD TALES AND OTHER

SHORT STORIES

W $580 \quad 60 \%$

RALPH WALDO EMERSON

SELECTED ESSAYS, LECTURES AND POEMS

W $608 \quad 60 c$

\section{HENRY DAVID THOREAL}

THE VARIORUM WALDEN

W $605 \quad 60 c$

HERMAN MELVILLE

BILLY BUDD AND TYPEE

W $556 \quad 60 c$

WALT WHITMAN

THE WHITMAN READER

GC $25 \quad 506$

MARK TWAIN

THE AUTOBIOGRAPHY OF MARK TWAIN W1075 SOC

A CONNECTICUT YANKEE IN

KING ARTHUR'S COURT

W $150 \quad 45 c$

\section{STEPHEN CRANE}

\section{MAGGIE AND OTHER STORIES}

THE RED BADGE OF COURAGE

W $133 \quad 45 c$

W $220 \quad 45 \&$
HENRY JAMES

THE AMBASSADORS

W $156 \quad 45 c$

UPTON SINCLAIR

OIL!

W $926 \quad 75 c$

ROBERT FROST

D A POCKET BOOK OF ROBERT FROST'S POEMS

W $912 \quad 754$

EDNA ST. VINCENT MILLAY

COLLECTED LYRICS

selected by the poet W 550606

$\square$ COLLECTED SONNETS

selected by the poet $\quad W 55160 c$

DRAMA

The ANTA Series of Distinguished Plays ... all ANTA editions include introductions and stage directions:

$\square$ THREE DRAMAS OF AMERICAN

REALISM

W $652 \quad 604$

Idiot's Delight, street Scene, The Time of Your Life

$\square$ THREE DRAMAS OF AMERICAN

Golden Boy. High Tor.

The Magnificent Yankee

$\square$ THREE PLAYS ABOUT BUSINESS IN AMERICA

The Aoding Machine,

Beggar on Horseback, All My Sons

$\square$ THREE PLAYS BY MAXWELL ANDERSON W $670 \quad 60 \mathrm{c}$ Joan of Lorraine, Valley Forge, Journey to Jerusalem

\section{POETRY ANTHOLOGIES}

[ NEW POCKET ANTHOLOGY OF AMERICAN VERSE FROM COLONIAL DAYS TO THE PRESENT

W $552 \quad 60 \%$

POCKET BOOK OF MODERN VERSE W 908 75\&

IMMORTAL POEMS OF THE ENGLISH W $909 \quad 75 \phi$
LANGUAGE

SHORT STORY ANTHOLOGIES

$\square$ MIDCENTURY, An Anthology of Dis. W 265 45c tinguished American Short Stories. 20 selections including works of Marquand, Michener, J. West and E. B. White.

MODERN AMERICAN SHORT STORIES W $224 \quad 456$ 19 selections including works by Hemingway, Steinbeck Caldwel Fitzgerald, Saroyan, Porter, and Thurber.

SPECIAL ANTHOLOGY

LIVING DOCUMENTS IN AMERICAN HISTORY

W1040 908

Over 60 significant documents

and songs of American history up to the civil War.

Washington Square Press, Inc., Dept. PMLA-10C

Educational Division

630 Fifth Avenue

New York, N.Y. 10020

Please send me one copy of each title checked

above. I enclose $\$$

(\$1.00 for each

3 titles checked).

Name

Affiliation

Address

City

State Zip

Please send me a catalog listing all of the Washington Square Press tities. 


\section{MLA CHARTER FLIGHTS}

5 DC-8 Jets with a 180-passenger capacity each have been chartered for the summer of 1967. Tentative schedule:

Flight \#1-New York-Brussels or Paris 8 June; return 8 Sept. (\$285)

Flight \#2-New York-Brussels or Paris 15 June; return 4 Sept. (\$285)

Flight \#3-New York-Brussels or Paris 24 June; return 27 Aug. (\$285)

Flight \#4-New York-London 29 June; return 30 Aug. (\$275)

Flight \#5-New York-Brussels or Paris 1 Aug.; return 11 Sept. (\$285)

Only those members will be eligible for MLA charter flights whose names appear in the September 1966 printed list of members (see PMLA, March 1966, p. A-6). Each MLA member will receive an application in the fall with final information on dates and flights. All inquiries should be directed to our authorized travel representatives:

\section{AIR-RES}

866 United Nations Plaza

New York City 10017

Tel: (212) 752-6671

AIR-RES will be happy to make other travel arrangements for MLA members.

\section{LARGE SELECTION OF RUSSIAN BOOKS for Teachers and Students of Russian}

- Russian Grammars and teaching aids

- English-Russian and Russian-English Dictionaries

- Russian Literature: Classics, Contemporary

- Russian Language Records for elementary and advanced students; dramatic readings and folk songs

- Textbooks on mathematics, geography, natural sciences, history, etc.
- Children's Literature

- Linguistics

- Literary Criticism

- Art

- Subscriptions to Magazines and Newspapers

- Socio-Economic Literature

- Atlases and Maps

\section{Write for Catalogs \& Prices}

Phone: (212) CH 2-4500

FOUR CONTINENT BOOK CORP.

DEPT. 658, 156 FITTH AVENUE, NEW YORK, N.Y. 10010 


\section{INDEX OF SECTIONS AND GROUPS}

Modern Language Association, 1966 Meeting, Statler Hilton and Sheraton Atlantic Hotels, New York City, Tuesday, Wednesday, and Thursday, 27,28 , and 29 December. We are pre-printing this list (which will appear in the official Program) to help members make their travel plans.

American Dialect Soctety-Tues. 3:00-4:15 (Red, Atlantic) $\quad \ldots \ldots \ldots \ldots \ldots \ldots \ldots \ldots \ldots \ldots \ldots \ldots$.

American Literature Section-Tues. 3:00-5:00 (Terrace Ballroom, Hilton) $\ldots . \ldots \ldots \ldots \ldots \ldots$....... American Literature-Tues. 10:30-11:45 A.M. (Grand Ballroom, Hilton) $\ldots \ldots \ldots \ldots \ldots \ldots \ldots$
A merican Studies Association-Tues. $8: 45-10: 00$ A.M. (Grand Ballroom, Hilton) $\ldots \ldots \ldots \ldots \ldots$ Celtic Lang. \& Lit.-Tues. 1:15-2:30 (Red, At-

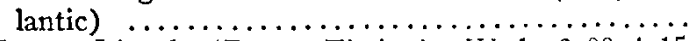
Comp. Lit. 1 (Prose Fiction)-Wed. 3:00-4:15 (Gold Ballroom, Hilton)

Comp. Lit. 2 (Popular Lit.) -Wed. 3:00-4:15 (Red, Atlantic)

Comp. Lit. 3 (Arthurian)-Wed. 10:30-11:45 A.M. (Colonial, Atlantic)

Comp. Lit. 4 (Renaissance)-Tues. 10:30-11:45 A.M. (Winter Garden Atlantic) ...............

Comp. Lit. 5 (Anglo-French)-Wed. 8:45-10:00 A.M. (Crystal, Atlantic) .................. Comp. Lit. 6 (Anglo-German)-1:15-2:30 (Blue,

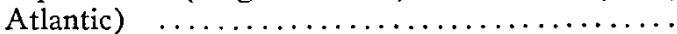
Comp. Lit. 7 (Franco-German)-Tues. 3:00-4:15 (Colonial, Atlantic)

Comp. Lit. 8 (Slavic \& Western Lit. Relations)Thurs. 8:30-9:45 A.m. (Colonial, Atlantic) ...... Comp. Romance Linguistics-Wed. 1 :15-2:30 (Ballroom, Atlantic)

Eng. Secrion II (after 1650)-Wed. 3:00-5:00 (Grand Ballroom, Hilton) ................

Eng. 1 (Old English)-Thur. 10:15-11:30 A.M. (Ballroom, Atlantic) $\ldots \ldots \ldots \ldots \ldots \ldots \ldots$

Eng. 2 (Middle English)-Tues. 10:30-11:45 A.M. (Georgian, Hilton) $\ldots \ldots \ldots \ldots \ldots \ldots \ldots \ldots$

Eng. 3 (Chaucer)-Thurs. 8:30-9:45 A.M. (Terrace Ballroom, Hilton)

Eng. 4 (Period of Spenser) - Tues. 8:45-10:00 A.M. (Winter Garden, Atlantic) ................

Eng. 5 (Shakespeare) -Wed. 8:45-10:00 A.M. (Terrace Ballroom, Hilton) ....................

Eng. 6 (Period of Milton)-Thurs. 10:15-11:30 A.M. (Gold Ballroom, Hilton) ...............

Eng. 7 (Classical Period) - Tues. 1:15-2:30 (Georgian, Hilton)

Eng. 8 (1750-1800)-Tues. 3:00-4:15 (Ballroom, Atlantic) $\ldots \ldots \ldots \ldots \ldots \ldots \ldots \ldots \ldots \ldots \ldots \ldots$ Eng. 9 (Eng. Romantics)-Wed. 10:30-11:45 A.M. (Terrace Ballroom, Hilton) ...............

Eng. 10 (Victorian Lit.) - Thurs. 10:15-11:30 A.M. (Terrace Ballroom, Hilton) ................

Eng. 11 (Contemporary) -Wed. 1:15-2:30 (Georgian, Hilton)

Eng. 13 (Present-Day Eng.) - Tues 8:45-10:00 A. (Georgian, Hilton) .....................

Eng. 14 (Eng. Drama)-Wed, 10:30-11:45 A.M. (Gold Ballroom, Hilton) ..................

ForUm I (Lit. \& Social Responsibility) - Tues. 2:004:00 (Grand Ballroom, Hilton).

Forum II (Lit. \& Social Psychology) - Wed. 10:00 A. A. $-12: 00$ (Grand Ballroom, Hilton) ...........

ForUm III (Romanticism) - Thurs. 10:15 A.M.-12:15 $12: 15$ P.M. (Grand Ballroom, Hilton) .........

French 1 (Ling. \& Med. Lit.) -Tues. 8:45-10:00 A.M. (Ballroom, Atlantic)

French 2 (16th Cent.) -Wed. 8:45-10:00

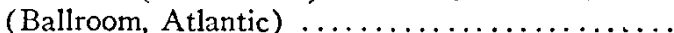

French 3 (17th Cent.)-Thurs. 10:15-11:30 A.M.

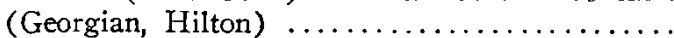

French 5 (18th Cent.) - Tues. 1:15-2:30 (Gold Ball-

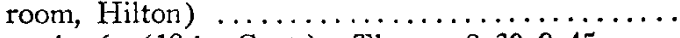

French 6 (19th Cent.)-Thurs. 8:30-9:45 A.M. (Georgian, Hilton) .................... 00

French 7 (20th Cent.) - Tues. 3:00-4:15 (Georgian,

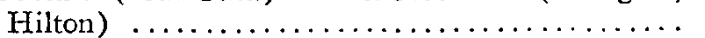

French 8 (North-Amer.)-Thurs. 8:30-9:45 A.M.

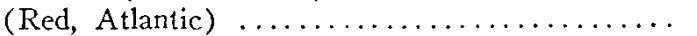

Gen. Top. 1 (Poetics) -Wed. 3:00-4:15 (Georgian, Hilton)

Gen. Top 2 (Romanticism)-Tues. 8:45-10:00 A.M. Gold Ballroom, Hilton) $\ldots \ldots \ldots \ldots \ldots \ldots \ldots$ Gen. Top. 4 (Gen. Linguistics) - Tues. 10:30-11:45 A.M. (Ballroom, Atlantic) ..................

Gen. Top. 5 (Exper. Phonetics)-Tues. 1:15-2:30 (Winter Garden, Atlantic) ................ 00

Gen. Top. 6 (Lit. \& Society) -Wed. 10:30-11:45 A.M. (Georgian, Hilton) .................

Gen. Top. 7 (Lit. \& Science)-Tues. 10:30-11:45 A.M. (Gold Baflroom, Hilton) ..............

Gen. Top. 8 (Bibliog. Evidence)-Thurs. 10:15$11: 30$ A.M. (Crystal, Atlantic) .................

Gen. Top. 9 (Lit. \& Other Arts) -Wed. 1:15-2:30 (Winter Garden, Atlantic) ................

Gen. Top. 10 (Lit. \& Psychology)-Tues. $3: 00-4: 15$ (Winter Garden, Atlantic) .................

German 1 (Philology)-Tues. 8:45-10:00 A.M. (Red, Atlantic) .........................

German 2 (Lang. \& Lit. to 1700)-Thurs. $8: 30-9: 45$ A.M. (Gold Ballroom, Hilton) .............. 00

German 3 (Goethe) -Wed. 8:45-10:00 A.M. (Gold

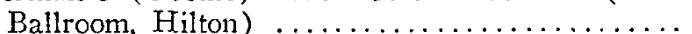

German 4 (19th Cent.) - Wed. 10:30-11:45 A.M. (Ballroom, Atlantic) ....................

German 5 (Modern Lit.) -Wed. 1:15-2:30 (Gold Ballroom, Hilton) ......................

Italian 1 (Med. \& Renaissance)-Tues. $1: 15-2: 30$

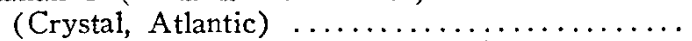

Italian 2 (Modern)-Tues. 3:00-4:15 (Crystal, At-

lantic) $\ldots \ldots \ldots \ldots \ldots \ldots \ldots \ldots \ldots \ldots \ldots \ldots \ldots \ldots \ldots \ldots \ldots$
Medeval Section-Wed. $3: 00-5: 00$ (Terrace Ballroom, Hilton) $\ldots \ldots \ldots \ldots \ldots \ldots \ldots \ldots \ldots \ldots \ldots$

Portuguese Lang. \& Lit.-Thurs. 10:15-11:30 A.M. (Colonial, Atlantic) .....................

Romance Section-Tues. 10:00 A.m.-12:00 (Terrace Ballroom, Hilton) ...................

Scandinavian Lang. \& Lit.-Tues. 10:30-11:45 A.M. (Red, Atlantic) $\ldots \ldots \ldots \ldots \ldots \ldots \ldots \ldots \ldots \ldots$

Slavic 1 (Literatures) -Wed. 1:15-2:30 (Green, At-

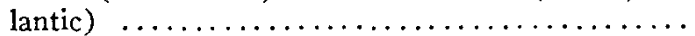

Slavic 2 (Linguistics) - Wed. 3:00-4:15 (Green, At-

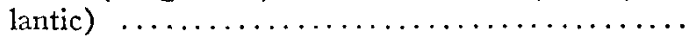

Spanish 1 (Lang. \& Med. Lit.)-Thurs. 8:30-9:45 A.M. (Ballroom, Atlantic) ....................

Spanish 2 (Ren. \& Golden Age)-Wed. 8:45-10:00 A.M. (Georgian, Hilton) ................

Spanish 3 (The Spanish Comedia) - Tues. 1:15-2:30 (Ballroom, Atlantic) ......................

Spanish 4 (18th \& 19th Cent.)-Wed. 3:00-4:15 (Ballroom, Atlantic) ....................

Spanish 5 (Modern Lit.)-Tues, 3:00-4:15 (Gold Ballroom, Hilton) .................... 00

Spanish 6 (Early Span.-Amer. Lit.) - Wed. 10:30$11: 45$ A.M. (Green, Atlantic) .............. 00

Spanish 7 (Modern Span.-Amer. Lit.)-Tues. 8:4510:00 A.M. (Green, Atlantic) ................

\section{0} 0 00 00 


\section{Significant Language Readers}

\section{BILLET CIRCULAIRE}

aLtCE LANGellien and PAUL LANGelier, Adelphi University. Teaching both language and civilization, this text presents aspects of old as well as contemporary France, touching upon history, geography, art, and culture. Carefully selected areas of France serve as a background for narratives and dialogues. $150 \mathrm{pp}$, illus., paper, \$1.95. Laboratory Exercises: two tapes, $\$ 15.00$ net.

\section{PRECIS DE CIVILISATION FRANÇAISE}

MINNE M. MILLE, Kansas State Teachers College, J. a. NIELson, U.S. Government; and JEAN LEBLoN, Hollins College. Written in French, these précis and objective tests deal with the history of France, French literature and art, and contemporary French life. 172 pp., illus., paper, $\$ 195$

\section{CONVERSATIONAL AND CULTURAL FRENCH}

JOSEPH PALMERI, The University of Wisconsin. A complete first-year introductory text for the study of the French language and culture, this book stresses a conversational approach but combines it with a thorough treatment of grammatical principles. $408 \mathrm{pp}$., $\$ 5.95$. Audiotapes will be available on loan for duplication or for purchase. Four tapes, $\$ 10.00$ net.

\section{TROIS NOUVELLES DE GEORGES SIMENON}

Edited by FRANk w. LINDSAY, Russell Sage College; and antmony M. Nazzaro, Skidmote College. These three nouvelles, Maigret et l'inspecteur Malgracieux, La Pipe de Maigret, and Sous Peine de mort, reveal Simenon's superb craftsmanship and his mastery of psychological realism. $228 \mathrm{pp}$., illus., paper, $\$ 2.40$

\section{AUSWAHL DEUTSCHER ESSAYS: VON SCHOPENHAUER BIS FRISCH}

Edited by Danien coogan, Brooklyn College; and EDMUND P. kURz, Queens College. Outatanding authors from 1850-1965 are represented in this new colloction of distinguished writings in the fields of literature, music, fine arts, politics, history, natural science, philosophy, theology, sociology, and psychology. 289 pp., illus., paper, $\$ 3.50$

\section{MODERNES DEUTSCH: EINE WIEDERHOLUNG DER GRAMMATIK MIT MODERNEN AUTOREN, 2nd Edition}

ERNA KRITsch, Douglass College, Rutgers University. Written entirely in German for the second-year student, this book strengthens vocabulary and grammar through the study of nonsimplified passages from modern German authors. 260 pp., illus., paper, $\$ 2.95$

\section{MENSCH UND ZEIT: ANTHOLOGY OF GERMAN RADIO PLAYS}

Edited by anNa otres, Antioch College. Six plays of rare merit, chosen for simplicity of language and style, are presented in this new anthology for intermediate and late first-year German. Audio tapes are available. 245 pp., illus., paper, $\$ 3.45$

\section{RACCONTI DEL NOVECENTO: FORTI E DEBOLI}

Edited by ILENE T. OLKEN, University of Michigan. Designed to introduce the student to the eontemporary Italian short story and novella, this anthology supplies needed reading material at the socond-yoar university level. $184 \mathrm{pp} .$, paper, $\$ 3.25$

\section{APPLETON-CENTURY-CROFTS}




\section{From $A \cdot C \cdot C$}

\section{FIVE RUSSIAN TEXTS}

Edited by G. A. BIRKETT, late of University of Glasgow. These intermediate readers feature a wide range of Russian writing, from nineteenth-century humanism through recent Soviet times. Equipped with notes and vocabularies, the stories were chosen for their literary qualities and for general interest.

ehrenburg's The Actress; and IVanov's Petya The Cock. 44 pp., paper, 954 FEDIN's Carp. 25 pp., paper, $95 \phi$

GoRkY's Ilya's Childhood and Children. 43 pp., paper, $95 \phi$

IVANov's The Saga of the Sergeant. 62 pp., paper, 95\%

Boronina's A Siberian Forest Adventure. 33 pp., paper, $95 \phi$

\section{CONTOS DO BRASIL}

D. LEE haMtLTON, Director, Language Development Branch, U.S. Office of Education; and NED CAREY FAHS, Director, Latin American Division, $W . K$. Kellogg Foundation. These sixteen short stories, designed to help the student learn about the language and the people of Brazil, are arranged according to difficulty. The selections cover a wide range of style from the conservative and classical to the colloquial idiom. Footnotes and brief summaries of the life and works of each author are included in Portuguese. 332 pp., paper, $\$ 3.95$

\section{TEATRO BRASILEIRO CONTEMPORÅNEO}

Edited by WILson Martins, New York University; and sEymour MENToN, University of California, Irvine. Sufficiently varied to appeal to all tastes, these five modern plays by Brazilian playwrights exemplify the real, spoken language of the contemporary Brazilian theatre. With an introduction, notes, vocabulary, exercises and drills, this book serves as a basic text for intermediate students of Portuguese and is also recommended for courses in Brazilian theatre. 405 pp., paper, $\$ 4.95$

\section{José López Rubio: LA VENDA EN LOS OJOS}

Edited by Marion P. HOLT, Queens College. In one of the most appealing serious comedies of the Spanish stage, López Rubio treats the role of illusion in the lives of his characters. A particularly effective text for classroom instruction, the play contains dialogue with allusions and references to various aspects of modern Spanish life--social, economic, and political -that are emphasized in the exercises and provide excellent conversational material for the development of oral proficiency. Designed for intermediate students the text contains a complete vocabulary and notes to clarify difficult constructions. 131 pp., paper, $\$ 1.95$

\section{Juan Antonio de Zunzunegui: CUENTOS Y PATRANAS}

Edited by REX E. Ballinger, Southwest Missouri State College. Filled with humor and lively imagination, these four "tall tales" explore all the facets of the author's native ria. The text is adapted for use in the last weeks of second-year Spanish study and beyond. It includes an introduction, bibliography, end-vocabulary, and questionnaires to aid comprehension of the text and for understanding of the work as a literary genre. $202 \mathrm{pp}$., paper, $\$ 2.45$ 


\section{GOLDENTREE BIBLIOGRAPHIES • SPRING 1966}

Goldentree Bibliographies, under the series editorship of O. B. Hardrson, JR., provide graduate and advanced undergraduate students with a convenient guide to scholarship on major literary figures, genres, and periods. Each bibliography contains from 1000 to 2000 numbered items, compiled by a recognized authority in the field. Emphasis is on work published in the twentieth century, and listings are arranged topically. An author index and extra space for call numbers and entries are provided. The volumes will be priced at approximately $\$ 1.25$. The first titles scheduled in the series are listed below.

LINGUISTICS AND ENGLISH LINGUISTICS

Compiled by HaRold B. Allen, The University of Minnesota.

VICTORIAN POETS AND PROSE WRITERS

Compiled by JEROME H. BUCKLEY, Harvard University.

MILTON

Compiled by JAMes Holly Hanford, Princeton University.

THE AMERICAN NOVEL THROUGH HENRY JAMES

Compiled by C. Hugh Holman, The University of North Carolina.

TUDOR AND STUART DRAMA

Compiled by IRvING RIBNeR, University of Delaware.

\section{NEW CROFTS CLASSICS}

Beaumarchais: The Barber of Seville

Trans. and edited by Brobury PEARce EuJs, Central Connecticut State College.

Beaumarchais: The Marriage of Figaro

Trans. and edited by Brobury Pearcz Ellis, Central Connecticut State College.

Browne: Hydriotaphia (Urn Burial) and The Garden of Cyrus

Edited by Franx L. HuntLey, The University of Michigan.

Browne: Roligio Madici

Edited by Frank L. HuntLeY, The University of Michigan.

Dryden: All for Love

Edited by JoHN J. ENCK.

Ford: 'Tis Fity She's a Whore

Edited by MARK STAvig, The University of Wisconsin.

Gay: The Beggar's Opera and Companion Pieces

Edited by C. F. Burgess, Virginia Military Institute.

Ibsen: Peer Gynt

Trans. and edited by KaI JuRgensen, The University of North Carolina; and RoBer T F. SchenkKan, The University of Texas. Introduction by John Simon.

Ibsen: The Wild Duck

Trans. and edited by Kal Jurgensen and Robert F. Schenkman, Introduction by John Simon.

Petrarch: Selected Sonnets, Odes, and Letters

Edited by ThOMAS GODDARD BergiN, Yale University.

Rabelais: Gargantua and Pantagruel: Selections

Trans. and edited by Flo YD GRAY, The University of Michigan.

Shakespeare: Troilus and Cressida

Edited by WILlaRd E. FARNhaM, University of California, Berkeley.

Sheridan: The School for Scandal

Edited by JoHN LoFTs, Stanford University.

Synge: The Playboy of the Western World and Riders to the sea Ediced by Wiluam E. HaRT, M.S., La Salette Seminary.

\section{APPLETON-CENTURY-CROFTS}




\section{NEW ENGLISH TEXTS}

\section{PRACTICAL RHETORIC}

O. B. HaRdison, JR., The University of North Carolina. This brief handbook of rhetoric emphasizes, as its title suggests, the practice rather than the theory of effective writing. Assuming the student to have a basic command of English grammar, the text moves from rhetorical fundamentals to specialized techniques of writing. Illustrations and exercises throughout are designed to build self-conscious habits in composing and editing. $350 \mathrm{pp}$., paper, $\$ 3.25$

\section{A PROGRAM FOR EFFECTIVE WRITING}

Robert L. Shurter, Case Institute of Technology; and James M. Rerp, Jr., Through this programmed text, the student is led to make decisions about organization, structure, and effective writing. Designed for freshman writing courses, the text may be used either in class or as homework coordinated with class instruction. $336 \mathrm{pp}$, illus., paper, $\$ 3.90$

\section{WORDS IN CONTEXT: A Vocabulary Builder, 2nd ed.}

A. A. DeVItis and J. R. WARner, both of Purdue University. Highly successful in its first edition, this book presents college level vocabulary in the context of modern essays rather than word lists. The second edition contains additional essays and several challenging new diagnostic tests. 333 pp., paper, $\$ 2.95$

\section{UNIFIED ENGLISH COMPOSITION, 4th ed.}

Gerald D. Sanders, formerly of Eastern Michigan Univetsity; Hoover H. Jordan, Eastern Michigan University; and Wallace H. Magoon, Ball State University. Economically combining complete materials for freshman composition under one cover, this major text includes the content of grammar, rhetoric, and reader, expertly organized and integrated for either a semester's or a year's work. The fourth edition features a more detailed table of contents and many new selections. An accompanying workbook is available only as a separate publication. $639 \mathrm{pp}$., double column, $\$ 5.95$

\section{SPELLING BY PRINCIPLES: A Programed Text}

Genevieve Love Smith, Research Director of Programed Instruction, Point Park Junior College. Correct spelling is seldom an explicit objective in the freshman English syllabus; yet departments other than English assume that somehow the student learns to spell accurately in freshman English. This programed text is a reliable solution to the problem, for it gives concentrated attention to spelling without any commitment of classroom time. 192 pp., 634 frames, paper, $\$ 2.90$

\section{AN APPROACH TO LITERATURE, 4th ed.}

Edited by Cleanth Brooks, Yale University; John T. Purger, Southeastern Louisiana College; and Robert Penn Warren, Yale University. The fourth edition of this well-known text, which stresses content as well as form, offers greater flexibility in teaching and features substantial changes in both the selections and editorial framework. 917 p p., double column, $\$ 7.50$

DIVISION OP MEREDITH PUBLISHING COMPANY - 440 PARK AVE., S., NEW YORK 10016 


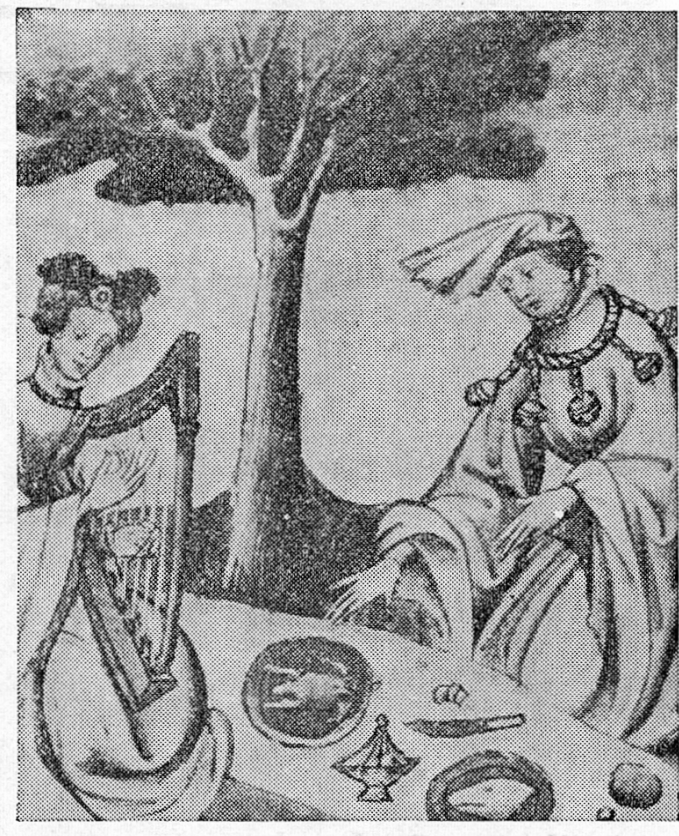

LE BOURGEOIS GENTILHOMME (Molière) Edited by CLAUDE K. ABRAHAM, University of Florida. Presents one of the great comedies of the classic French theatre with notes and questions designed explicitly for the American college student. The vocabulary, footnotes, questions-in short, the entire pedagogical apparatus-is aimed at a modern young American audience at a time when it is beginning to gain a mastery of literary analysis. January 1966, 138 pp., paperbound $\$ 2.50$

GENITRIX (Mauriac) Edited by JOHN PORTER HOUSTON and MONA TOBIN HOUSTON, both of Indiana University. This twentieth-century short novel by Nobel Prize-winner François Mauriac is a model of simple, elegant French. Its theme is the conflict among members of a bourgeois family, and its setting, magnificently described, is a small town near Bordeaux at the turn of the century. Every attempt has been made to explain and explore both linguistic and literary problems in the notes and questions. May 1966, 89 pp., paperbound $\$ 1.95$

LE CID (Corneille) Edited by A. DONALD SELLSTROM, University of Texas. Dramatizes a series of extraordinary triumphs as its hero succeeds in reconciling the demands of personal honor with loyalty to his king and love for his mistress. Questions at the end of each act are designed to lead the student through the complexities of Cornelian rhetorical argumentation to a broad understanding of the aesthetic and human values of the work. March 1967, approx. 128 pp., \$1.95

\section{MASTERPIECES OF FRENCH LITERATURE SERIES}

\author{
Editor: Robert L. Politzer \\ Stanford University
}

ON NE BADINE PAS AVEC L'AMOUR (Musset) Edited by JEAN CARDUner, University of Michigan. Prepared with the American student of the 1960's in mind, this edition of Musset's play will help him read and savor its wit and insights without having to struggle with unnecessary linguistic difficulties. The questions at the end of each act gradually take the student from factual discussion into psychological and literary interpretation; footnotes offer vocabulary and background information. January 1967, approx. $96 \mathrm{pp}$., paperbound $\$ 1.75$

PROGRAMMED DICTIONARY FOR MASTERPIECES OF FRENCH LITERATURE Edited by ROBERT L. POLITZER, Stanford University. The two primary features of this dictionary are its unique program apparatus and its French orientation, a combination that presents the student with a pedagogical tool heretofore unavailable.

The programming permits the student to record the number of times he looks up each word. Thus he is able to realize the importance of the word and the fact that after looking it up a certain number of times (six times) it should be a part of his working vocabulary.

The second feature is the nature of the entries themselves, each of them defined in basic French rather than in English (though in cases of special difficulty an English equivalent is also provided). This permits the student to work directly in the foreign language. September 1966,83 pp., $\$ 1.45$

TRISTAN ET ISEUT Modern French Edition by DONALD STONE, JR., Harvard University. Gives the student with no knowledge of old French the opportunity to read this world-renowned love story in a modern text that preserves as closely as possible the style of the original. The only text to make a distinction between the version commune and the version courtoise, Professor Stone's provides the historical background necessary for the interpretation of both versions. September 1966, 135 pp., paperbound $\$ 2.50$

\section{DE JEU DE L'AMOUR ET DU HASARD (Marivaux)}

Edited by J. B. RATERMANIS, University of Iowa. A comedy of the 18th century. The text is accompanied by explanatory notes (in French) making it accessible to the student of average proficiency. Appropriate for use in an intermediate or advanced language course, as well as in an 18th century literature course. March 1967, approx. 112 pp., $\$ 1.95$ 


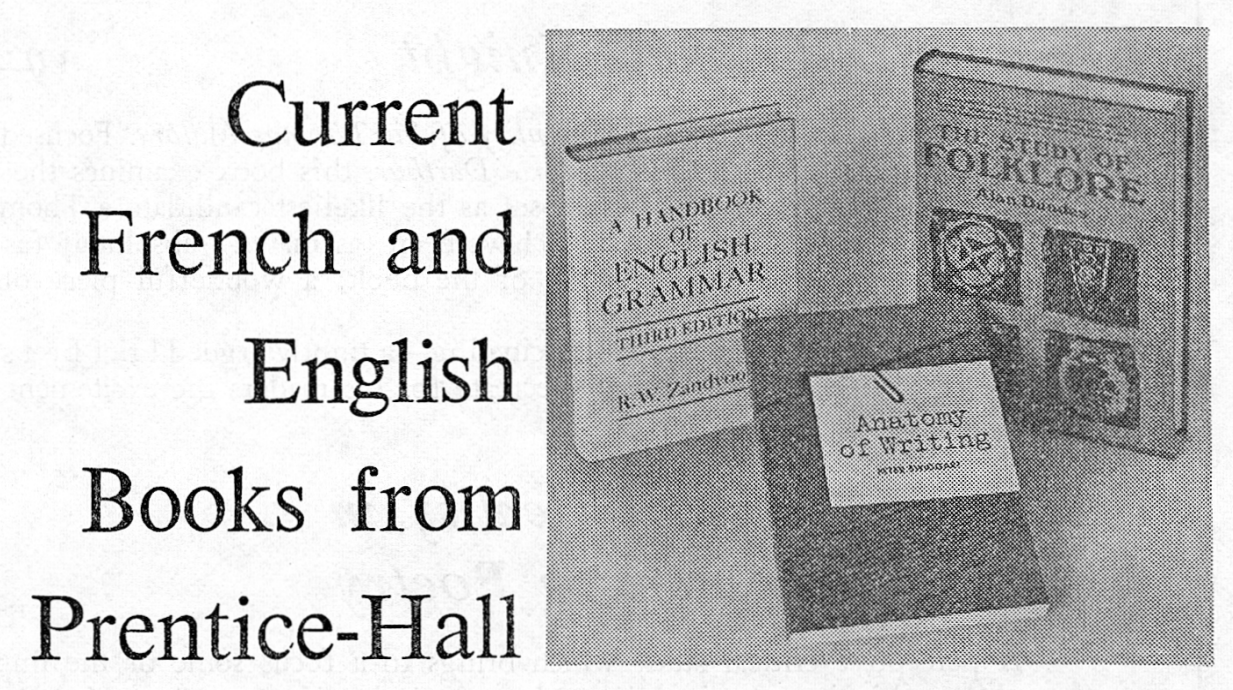

THE STUDY OF FOLKLORE by ALAN DUNDES, Uni- ANATOMY OF WRITING by PETER SWIGGART, versity of California at Berkeley. The first anthology in Brandeis University. A new composition approach to English devoted to the discipline of folklore, this text con- language study. Dr. Swiggart combines instruction in tains a broad and comprehensive examination of the logic and language meaning with practical procedures theory and method of the subject. Combining humanistic for the writing of themes and correction of writing misand social scientific approaches, it includes contributions takes. The book provides specific and challenging by 34 authorities on the essence of folklore, its origins, theme assignments that expose the integral relationand its study. Featured are introductions to each of the ship between writing and thinking errors, and ensix sections written by the editor, a trained folklorist, courages students to pay close attention to language with the beginning student in mind. 1965,481 pp., $\$ 6.50$ detail. While serving the composition course, ANATOMY oF WRITING also provides an effective bridge between a course in rhetoric and an introduction to literature. The self-conscious attention that good writers pay to

A HANDBOOK OF ENGLISH GRAMMAR, Third Edition, 1966 by R. w. ZANDVOORT, University of Groningen. This is the first United States printing by an American publisher of a compact and comprehensive text that has long been recognized as "the best one-volume traditional grammar in English." In his Preface, DR. ZANDVOORT describes his book as a "text that deals with accidence and syntax, leaving aside what belongs rather to idiom and is not amenable to the general statement." January 1966, 349 pp., $\$ 5.95$.

Illustration, upper left: Isolde plays the harp to entertain Tristan at a picnic-from a 15 th Century manuscript. Courtesy of The Bettmann Archive.

(Prices shown are for student use.)

FOR APPROVAL COPIES, WRITE: Box 903

PRENTICE-HALL Englewood Cliffs, N.J. 07632 


\section{The Ill-Framed Knight}

WILLIAM MATTHEWS

A Skeptical Inquiry into the Identity of Sir Thomas Malory. Focused on identifying the real author of the classic Le Morte Darthur, this book examines the lives and claims of four Thomas Malorys and proposes as the likeliest candidate a Thomas Malory who has never before been considered. "I have been fascinated-absolutely fascinated by this. . . Am enchanted by the substance of the book: a wonderful piece of research."-Hugh Trevor-Roper

"I found the whole document fascinating - a tightly argued brief by a scholar who relished the research and knew how to recreate for his readers the excitement of clever finds."Albert B. Friedman $\$ 6.50$

\section{Conceptions of Reality in Modern American Poetry}

L. S. DEMBO

A perceptive critical study which brings to a focus some of the important literary and philosophic issues raised in 20th-century American poetry. Mr. Dembo contends that despite great differences in temperament and idiom, poets so diverse as John Gould Fletcher, H. D., Amy Lowell, William Carlos Williams, Wallace Stevens, Marianne Moore, e. e. cummings, Hart Crane, Pound, and Eliot adhere to a common aesthetic philosophy. $\$ 6.00$

\section{Marina Cvetaeva}

SIMON RARLINSKY

Her Life and Art. Marina Cvetaeva (1892-1941) was one of the great Russian poets of the 20th century, comparable to Axmatova, Mandelstam and Pasternak. Yet, because of the political circumstances surrounding her life, she died by her own hand and in obscurity, and not until the "thaw" of a decade agol did her work begin to be revived in Soviet or western criticism. This is the first full-scale critical and biographical study of Cvetaeva to be published in any language. $\$ 7.25$

\section{The Transformation of the Roman World}

Edited by LYNN WHITE, jr.

Gibbon's Problem after Two Centuries. In this reëvaluation of the problems raised by Gibbon in The Rise and Fall of the Roman Empire, a group of historians examines the changes in historical perspectives between Gibbon's time and the present day. The book deals with what happened, as we now see it, in the age of the Roman world's transformation; why Gibbon saw things as he did; and why our angle of vision differs from Gibbon's. Contributions of the UCLA Center for Medieval and Renaissance Studies: III $\$ 6.00$

\section{The New Comparative Mythology}

C. SCOTT LITTLETON

An Antbropological Assessment of the Theories of Georges Dumézil. A thoughtful anthropological assessment of the theories and methods developed by one of the greatestand most controversial-figures in the movement to relate myth to social structure and function: Georges Dumézil of the Collège de France. Dumézil has attempted to assign three essential kinds of function to all societies claiming Indo-European descent: the priestly, the warrior, and that of the husbandman. $\$ 5.95$

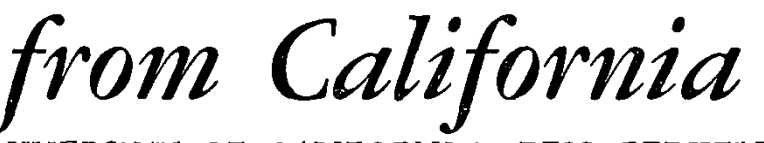

UNIVERSITY OF CALIFORNIA PRESS, BERKELEY 94720

PMLA A- 48 


\section{Modern Language Grammars from Scribners}

FRENCH

BASIC FRENCH: An Oral Approach

Bruce H. Mainous, University of Illinois. 1961. xvii, 535 pp. 45 photographs. 3 maps. Cloth. $\$ 5.75$.

A CONVERSATIONAL FRENCH REVIEW GRAMMAR

James J. Kearney, Fordham University and Catherine Rita Martin, Fordham University. Second Edition. 1961. xx, 267 pp. Cloth. $\$ 4.50$.

L'ESSENTIEL DE LA GRAMMAIRE FRANCAISE

Léon-François Hoffmann, Princeton University. 1964. xvi, 203 pp. Cloth. \$3.95. Travaux pratiques, 1964. 160 pp. Paper. \$2.50.

GERMAN

BASIC GERMAN: An Introduction

Herbert Lederer, Queens College. 1966. xiv, 225 pp. Cloth. \$3.95.

DEUTSCHE SPRACHLEHRE FUR AMERIKANER

Dora Schulz, Goethe Institut, Munich, Heinz Griesbach, Bad Reichenhall, and Harold von Hofe, University of Southern California. 1965. 380 pp. Ilustrations. Cloth. \$6.25. Supplement, 1965. 128 pp. Paper. \$1.95.

\section{DAS ERSTE JAHR}

Margaret Keidel Bluske, Cerritos College and Elizabeth Keidel Walther, Cerritos College. 1965. xx, 396 pp. Cloth. \$5.95. Lab manual, 1965. 155 pp. Paper. \$2.95.

DAS ZWEITE JAHR, Buch I

Margaret Keidel Bluske, Cerritos College and Elizabeth Keidel Walther, Cerritos College. Spring, 1967. Cloth. About $\$ 5.50$.

\section{DEUTSCHE STUNDEN}

Allen I. Weinstein, Edgar N. Mayer, Barry J. Karp, Alice Carol Gaar, Willard Ticknor Daetsch, and Dennis J. Mahoney. 1964. 402 pp. Illustrations. Cloth. $\$ 7.50$.

TOWARD FLUENCY IN SPEAKING AND WRITING GERMAN

Erich Hofacker, Washington University, St. Louis. 1963. 275 pp. Photographs. Cloth. \$4.75.

SPANISH

\section{ESSENTIALS OF SPANISH THROUGH PRACTICE}

Herbert A. Van Scoy, Arizona State University and Margaret M. Davis. 1959. xii, 212 pp. Cloth. $\$ 3.95$.

\section{A NEW SHORTER SPANISH REVIEW GRAMMAR}

Juan Rodríguez-Castellano, Duke University and Charles Barrett Brown. 1958. x, 225 pp. Cloth. $\$ 3.95$

TODAY'S SPOKEN SPANISH

Rodger A. Farley, United States Naval Academy and Laura Argüelles de Farley. 1964. xii, 267 pp. Photographs. Cloth. \$4.50.

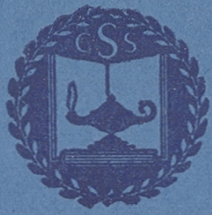

\section{CHARLES SCRIBNER'S SONS}

College Department 597 Fifth Avenue - New York 
NOW AVAILABLE FROM NEW YORK UNIVERSTTY PRESS

\section{GERMAN GRAMMAR III}

by Peter Jørgensen

translated by $\mathrm{G}$. Kolisko

September 220 pages $\$ 6.00 \mathrm{~N}$

This third and final volume is concerned with the use of verbal forms, congruence, word order, and sentences. Peter Jørgensen is Professor of German at the University of Copenhagen and Gertrude Kolisko is Lecturer in German at the University of Sheffield, England.

Previously published

GERMAN GRAMMAR I AND II

each volume $\$ 4.75 \mathrm{~N}$

"The English version of Jørgensen's Tysk grammatik ... should be welcomed by all those engaged in the teaching of advanced German composition, syntax, and stylistics. Here we have a concise, yet thorough, presentation of the elements of German grammar in accord with the more recent advances in the analysis of grammatical structure and in a generally lucid style which makes the work suitable for use with students of uncertain sophistication in the realm of grammatical theory. . . .

"Volume I contains an Introduction and seven chapters on Word-Formation, The Declension of Nouns, Adjectives, Adverbs, Pronouns, Numerals, The Conjugation of Verbs, an Appendix listing strong, irregular weak and mixed verbs, and an index of Words and Subjects. Volume II consists of a single chapter devoted to Number and Case, with an Index of Words and Subjects. ... I believe most readers will find that there are many more sound than unsound features in this grammar. Possible differences of opinion ... can lead to very fruitful class discussion, stimulate students to contemplate the problems, and perhaps even convince some of them that the study of grammar is not so cut and dried a subject as the neat formulations of many of our elementary textbooks would suggest."-Elmer H. Antonsen in the Journal of English and Germanic Philology

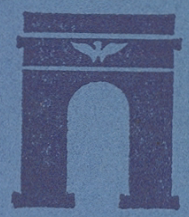

NEW YORK UNIVERSITY PRESS · 32 WASI TINGTON PLACE · N. Y. 10003 